\title{
Wacana kolonial dalam film Moeder Dao, de schildpadgelijkende ${ }^{1}$
}

\author{
JUGIARIE SOEGIARTO
}

\begin{abstract}
Documentary maker Vincent Monnikendam compiled the film Mother Dao, the turtlelike (1995) from more than 200 titles of archived films of the Dutch-Indies, shot between 1912 to ca. 1933. This film is neither a remake nor an edited version, but a kind of collage from those hundreds of archival films, all were silent. Monnikendam re-arranged the images and provided them with a new sound frame, consisting of songs, chantings and poems, in Indonesian, Old Javanese, and Sundanese. This new composition is not just creative but also quite provocative. With this arrangement the cineast wanted to show that there was something not quite right with colonialism. Through the new composition of images and the sound framing we can observe the power relation between the colonizer and the colonized. There are contrasts between the colonial and the colonized, literally as well as metaphorically. These contrasts raised some questions about the colonial discourse.
\end{abstract}

KEYWORDS

Hindia-Belanda, film dokumenter, wacana kolonial, kritik poskolonial, relasi kuasa.

Film adalah media representasi yang dihasilkan dari tindakan pembacaan atas realitas yang tak terbatas, yang tak mungkin mampu digambarkan secara utuh. Film Moeder Dao, de schildpadgelijkende; Een kinematografische verbeelding van Nederlandsch-Indië van 1912 - ca. 1933 (judul film dalam versi pertama) atau Mother Dao, the turtlelike; A kinematographic image of the Dutch-Indies 1912 - ca. 1933 'Ibu Dao, bak penyu; Suatu penggambaran kinematografis Hindia-Belanda, 1912 - \pm 1933 ' (selanjutnya disingkat MD) yang ditayangkan perdana pada tahun 1995 adalah film produksi Nederlandse Programma Stichting (NPS, Lembaga

Tulisan ini semula merupakan makalah untuk mata kuliah Metode Penelitian Sastra pada Program Pascasarjana Susastra, Fakultas Ilmu Pengetahuan Budaya, Universitas Indonesia. Makalah itu kemudian mengalami banyak penyesuaian untuk pemuatannya dalam jurnal ini.

JUGIARIE SOEGIARTO adalah staf pengajar pada Program Studi Belanda dan Departemen Kewilayahan, Fakultas Ilmu Pengetahuan Budaya, Universitas Indonesia; mendapat gelar Magister dalam bidang Ilmu Susastra dari Fakultas yang sama pada tahun 1990; mempunyai minat pada kajian Sastra Belanda Modern dan kajian film cerita dan dokumenter. 
Program Penyiaran Belanda) dan hasil kreasi sutradara Vincent Monnikendam. Film ini (lihat Gambar 1) dibuat dan dihasilkan ketika ia bertugas di Nederlands Omroep Stichting (NOS, Lembaga Penyiaran Belanda).

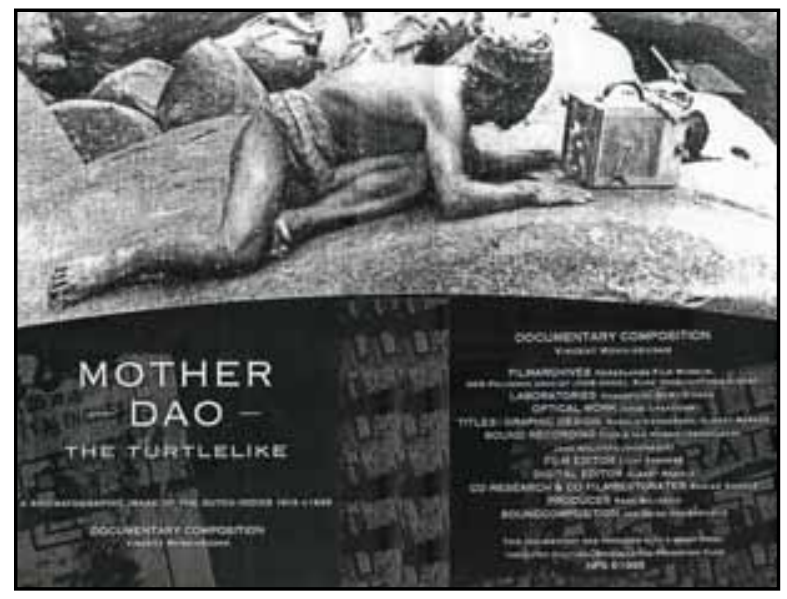

Gambar 1: Sampul kotak video film Mother Dao, the turtlelike.

MD bukanlah merupakan remake, yaitu film lama yang dibuat kembali, tetapi merupakan karya kolase yang disusun dari sejumlah penggalan film dokumenter yang dibuat di Hindia-Belanda antara tahun 1912 dan kira-kira tahun 1933. Meskipun MD adalah hasil rangkaian dari sejumlah penggalan film-film Hindia-Belanda, tidaklah berarti bahwa MD mengemban 'beban pesan' yang sama sebagaimana yang dimiliki oleh film-film dasar itu. MD tidak dapat dianggap sebagai representasi asli dari Hindia-Belanda. Filmfilm Hindia-Belanda yang dibuat oleh orang Belanda/Eropa terlihat jelas dimaksudkan untuk menyebarkan pengetahuan tentang Hindia-Belanda dan memberikan pemahaman perihal kebijakan pemerintah Hindia-Belanda kepada masyarakat Belanda, serta untuk menghapus citra yang keliru tentang wilayah jajahan yang berkembang di kelompok masyarakat Belanda yang berhaluan liberal masa itu. Semenjak dicanangkannya kebijakan politik etik (1902) dan berkembangnya pemikiran liberal di Belanda, berkembanglah pula wacana yang begitu kritis mengkaji kekuasaan kolonial di seberang lautan.

MD dibuat untuk 'memperlihatkan kembali' situasi di Hindia-Belanda kepada publik masa kini melalui penggalan film kala itu yang diproduksi atas pesanan dari pemerintah Hindia-Belanda dan untuk kebutuhan masyarakat Belanda di masa kolonial. Dengan memanfaatkan film-film Hindia-Belanda, semuanya kurang lebih 1.144 can (kaleng kemasan), yang masing-masing berisi gulungan film sepanjang kira-kira 220 meter pita film, meliputi lebih dari 200 judul, Monnikendam merangkai MD sepanjang 90 menit. Berbeda dengan film-film Hindia-Belanda yang bisu, MD dilengkapi dengan suara pengiring. Monnikendam dalam usulan proyek yang ditulisnya ketika hendak membuat film ini menyatakan berniat membuat suatu komposisi kreatif yang sama 
sekali baru dan berkesinambungan; suatu interpretasi dan representasi yang sama sekali baru dan suatu interpretasi dan representasi yang bisa dipercaya, walaupun mungkin subjektif. ${ }^{2}$

Dengan menambah sonor, yaitu suara yang mengiringi gambar berupa bunyi, tembang, puisi Indonesia modern, dan cerita mitos Nias, Monnikendam berupaya untuk menuturkan suatu cerita tentang Hindia-Belanda dengan cara merangkai beragam penggalan film tanpa kronologi tahun pembuatan atau kejadian ataupun tempat dan topik masing-masing film aslinya.

Apa yang dimaksud Monnikendam (1992) dengan 'interpretasi dan representasi yang bisa dipercaya' mengacu pada apa yang menjadi tujuan awal pembuatan film Hindia-Belanda, yang menurut interpretasi Monnikendam adalah wacana kolonial. Wacana kolonial adalah konteks dan situasi kolonial yang memperlihatkan hubungan serta mentalitas orang Belanda/Eropa yang berkuasa baik di jajaran pemerintah maupun di dunia usaha dengan wilayah dan masyarakat yang dikuasainya, misalnya: hubungan antara para petinggi pemerintahan kolonial dan para pegawai rendahan, begitu pula hubungan hierarkis di dalam dunia usaha, misalnya perlakuan dari direktur yang seringkali juga pemilik perusahaan dan para mandor di lapangan sebagai satu pihak yang berkuasa terhadap warga koloni yang berada di bawah kekuasaan mereka. ${ }^{3}$ Monnikendam (1992: 6) menyatakan bahwa film-film Hindia-Belanda itu terlihat ' polos dan gamblang' dalam tujuan propagandanya. Atas dasar ini Monnikendam sebagai sineas pengolah wacana kolonial kemudian memilih, memilah, dan menyusun pelbagai penggalan film Hindia-Belanda yang lama itu dengan kreatif demi mewujudkan interpretasinya, baik interpretasinya atas film-film Hindia-Belanda itu maupun apa yang ingin ditampilkannya.

Dalam MD diperlihatkan 55 sekuen $^{4}$ topik kejadian yang tak terputus. Kelima puluh lima sekuen yang memperlihatkan wacana kolonial ini masingmasing diberikan judul. ${ }^{5}$ Dalam semua sekuen ini topik gambar yang paling sering terlihat berulang adalah tentang kuli. Dari deretan sekuen ada tiga di antaranya dengan kata 'kuli' muncul dalam tajuknya, yaitu sekuen 19, 44, dan 51. Ketiga sekuen ini yang terutama akan dibahas dalam tulisan ini.

\section{KOLONIALISME DAN WACANA KOLONIAL}

Kolonialisme, penguasaan, dan pengendalian suatu wilayah oleh bangsa lain, bermula dengan penguasaan berbagai wilayah Asia dan Afrika oleh bangsa-bangsa Eropa. ${ }^{6}$ Penguasaan kawasan Asia dan Afrika pada abad sembilan belas selain merupakan ekspansi wilayah bangsa-bangsa Eropa dalam upaya mencari sumber bahan mentah, membuka pasar, sekaligus pertandingan kekuasaan. Dalam perkembangannya penguasaan wilayah itu bukan hanya berkaitan dengan kepentingan ekonomi dan politik, tetapi juga

\footnotetext{
$2 \quad$ Monnikendam 1992: 6.

3 Monnikendam 1992: 6.

4 Adalah rangkaian gambar yang membentuk satuan makna (Bordwell dan Thompson 1993: 496). Sekuen mencakup sejumlah shot.

5 Lihat daftar judul sekuen dalam Lampiran.

$6 \quad$ Williams dan Chrisman 1993: 2.
} 
penguasaan budaya. Bangsa penguasa mengubah kawasan yang dikuasainya menjadi seperti wilayah tempat asal mereka, dengan mengabaikan budaya dan masyarakat yang telah ada sebelum kedatangan mereka.

Kekuasaan Belanda atas Indonesia berawal dari kedatangan para pedagang pencari rempah pada abad enam belas. Peperangan dengan Portugal dan Spanyol, yang diikuti dengan penutupan pelabuhan dan terhentinya pasokan, memaksa para pedagang Belanda untuk mencari sendiri sumber barang dagangan itu ke tanah penghasilnya dan sekaligus berupaya menguasai pasar. Lebih lagi pada masa itu rempah-rempah merupakan barang dagangan yang diminati dan karenanya sangat menguntungkan. ${ }^{7}$ Untuk mengatasi persaingan antarpedagang Belanda dan demi untuk mengendalikan pasar dibentuklah suatu serikat dagang yang menyatukan para pedagang Belanda itu, yaitu VOC (Vereenigde Oost-Indische Compagnie), 'Serikat Dagang Hindia Timur'. VOC adalah persatuan dagang swasta yang berpusat di Batavia. Ketika VOC bangkrut pada akhir abad delapan belas, maka Serikat Dagang Hindia Timur itu diambil alih pemerintah kerajaan Belanda. Sejak itu penguasaan tidak hanya terbatas pada urusan dagang saja dengan munculnya pemerintahan kolonial, yaitu ketika di Hindia diangkat seorang gubernur jenderal sebagai wakil resmi pemerintah kerajaan Belanda pada akhir abad sembilan belas. ${ }^{8}$ Sejak saat itu wilayah Hindia secara resmi menjadi bagian dari kerajaan Belanda. Sementara itu, di negeri Belanda dibentuk suatu departemen khusus, Ministerie van Koloniën, yang mengurus wilayah jajahan. ${ }^{9}$ Departemen itu menentukan dan memutuskan kebijakan pemerintah di Hindia-Belanda. Semenjak menjadi bagian dari kerajaan sejak akhir abad sembilan belas, Hindia-Belanda seringkali disebut sebagai provinsi (Belanda) di seberang lautan dan menjadi wilayah yang berfungsi sebagai pemasok kebutuhan pasar. ${ }^{10}$

Seperti yang telah disebutkan sebelumnya, bahan film dasar yang dimanfaatkan untuk merangkai MD adalah film-film yang dibuat di HindiaBelanda pada awal abad dua puluh. Film-film tersebut ketika itu dibuat atas pesanan berbagai pihak seperti lembaga pemerintah, perusahaan dagang, lembaga gereja, dan lembaga sosial swasta. Film-film itu dimaksudkan sebagai bahan penerangan, informasi, dan bahkan propaganda. Lembaga gereja, misalnya, membuat film itu untuk mendorong para rohaniwan agar melakukan pekerjaan dakwah dan sebagai laporan kemajuan pekerjaan gerejawi yang didanai oleh jemaat, sekaligus untuk menghimbau warga gereja agar memberikan dukungan dana lebih lanjut demi pemekaran dan pekerjaan gereja. Bagi lembaga pemerintah film-film yang mereka pesan selain menjadi dokumen sebagai kelengkapan arsip, juga dipakai sebagai bahan penerangan bagi masyarakat luas. Film-film itu tidak saja ditonton oleh para calon pegawai pemerintah dan mahasiswa jurusan Indologi yang mengkhususkan perhatiannya pada kajian Hindia tetapi film-film itu juga menjadi bagian kurikulum pelajaran di sekolah, yang dimaksudkan sebagai propaganda untuk memahami bahwa 'di sana di Hindia suatu karya atau

De Jong 1998: 35.

Lihat De Jong 1998 mulai halaman 381 dan seterusnya; Van Doorn 1994 mulai hlm. 29.

Maters 2003: 426.

Hellwig 2007: 11. 
pekerjaan besar sedang dilakukan' ${ }^{11}$ Bagi perusahaan-perusahaan, film-film tersebut selain berfungsi sebagai dokumen arsip, juga dilihat sebagai bentuk laporan kepada perusahaan induk dan dianggap sangat bermanfaat sebagai alat pemasaran di bursa dagang.

Pemerintah Hindia-Belanda abad dua puluh, meski tetap didasari konsep imperialisme dan kolonialisme, adalah penguasa yang sedang menjabarkan gagasan dari politik etik, yang dicetuskan oleh Van Deventer pada tahun 1902. Gagasan tersebut berasal dari pemikiran kaum etik Belanda, yang dipengaruhi oleh ide pencerahan. Kaum etik Belanda berpendapat bahwa Hindia-Belanda harus dikelola, bukan diperlakukan sewenang-wenang dan semata-mata hanya dijadikan sebagai tempat mencari keuntungan. Dianggap sudah saatnya pemerintah Belanda mengembalikan keuntungan yang sudah diperolehnya selama itu. Penderitaan warga Hindia harus diakhiri, penduduk Hindia harus dientaskan dari kemiskinan. Politik etik itu karena itu disebut juga dengan ereschuld 'balas budi'. ${ }^{12}$ Kebijakan politik ini muncul sebagai reaksi atas keadaan di Hindia-Belanda. Pokok perhatian kaum liberal yang berkuasa di Hindia-Belanda pada waktu itu adalah pembangunan ekonomi. Dasar kebijakan pemerintah adalah 'menghasilkan keuntungan'. Kebijakan pemerintah itu berujung pada penerapan sistem tanam paksa (1830-1835), yaitu peraturan yang mewajibkan petani pribumi untuk menanam produk yang laku di pasar Eropa, seperti kopi, tebu, teh, indigo, dan kemudian tembakau. Kewajiban itu sangat memberatkan para petani karena tanah yang tersisa tidak menghasilkan padi dan tanaman pangan lain, yang diperlukan mereka untuk memenuhi kebutuhan sehari-hari.

Penerapan politik etik itu atau 'balas budi' tertuang dalam kebijakan pengembangan tiga sektor, yaitu irigasi, pendidikan, dan emigrasi. ${ }^{13}$ Sebenarnya hampir semua film Hindia-Belanda itu dimaksudkan selain untuk memperlihatkan pekerjaan-pekerjaan yang besar yang dilakukan oleh pemerintah Hindia-Belanda dengan semangat 'balas budi' itu, juga untuk mempropagandakan Hindia-Belanda sebagai pemasok devisa Belanda yang penting. ${ }^{14}$ Beberapa film juga menunjukkan prestasi warga Belanda di Hindia-Belanda baik dalam bidang ekonomi maupun sosial. Sementara itu, film gerejawi menggarisbawahi pentingnya menyadarkan penduduk asli yang non-Kristen agar menjadi anggota gereja. Namun, tentu saja gambaran yang positif di film untuk mata Belanda dengan menyoroti penyediaan sarana pendidikan dan kesehatan bagi warga pribumi di masa kolonial tetap memperlihatkan perbedaan perlakuan antara warga Eropa dan pribumi. Sementara itu, film-film yang mengangkat kehidupan seni dan budaya masyarakat di berbagai kepulauan di luar Jawa, seringkali menjadikan budaya Jawa atau Eropa sebagai tolok pembanding.

11 Propaganda yang didengungkan dengan semboyan "Daer can in Indiën wat groots verricht worden" berasal dari Jan Pieterszoon Coen (1587-1629) (Van Helsdingen 1941: vi).

12 De Jong 1998: 291-293.

13 Lihat De Jong (1998) mulai halaman 419.

14 Pada periode 1830-1874 jumlah uang yang masuk ke kas kerajaan sebagai perolehan dari Hindia mencapai sepertiga dari pendapatan pemerintah (Naeff 1978: 5). 
Wacana kolonial yang dapat dipahami sebagai beragam representasi dan cara pandang yang digunakan kekuasaan kolonial agar subjek kolonial tetap tunduk pada aturan-aturan kolonial, terlihat dengan jelas dalam film-film Hindia-Belanda itu. Berlindung di balik tiga sektor kebijakan etik - irigasi, edukasi, emigrasi - perusahaan kolonial dikembangkan. Irigasi memang dibuat tetapi yang mendapat manfaat adalah perkebunan besar milik Belanda/Eropa. Demikian pula halnya dengan emigrasi, yang terlihat di film adalah mutasi penduduk karena kontrak kerja, berkaitan dengan kebutuhan tenaga kerja perusahaan pertambangan dan perkebunan, baik milik pemerintah maupun swasta. Film yang merekam kegiatan pendidikan memperlihatkan beragam jenis sekolah seperti sekolah Cina berbahasa Belanda, sekolah desa di Jawa, sekolah Eropa. Namun, kesemuanya ini merupakan sekolah yang dipilahpilah berdasarkan agama, ras, dan golongan. Bagi pemerintah Hindia-Belanda, film-film itu adalah bukti bahwa pemerintah telah menjalankan kebijakan etik. Pemerintah Hindia-Belanda dapat memberikan laporan konkret pada pemerintah dan sekaligus menunjukkan pada masyarakat Belanda tentang pengelolaan wilayah koloni. Tambahan pula, film-film dokumenter itu dibuat dengan prinsip peindre sur le vif 'sebagaimana sebenarnya' sehingga tidak ada alasan bagi kaum etik untuk mempersalahkan pemerintahan di HindiaBelanda karena tidak mengelola wilayah koloni dengan baik.

\section{MAKSUD SINEAS DAN REAKSI PUBLIK}

MD dimaksudkan oleh Monnikendam (1992: 9) sebagai chaîne signifiante, rangkaian makna yang terbentuk dalam suatu struktur, yang merepresentasikan relasi kuasa di masa kolonial pada penontonnya. Sineas Monnikendam berusaha membantu penonton membangun persepsinya sendiri tentang relasi kuasa masa kolonial dengan cara merangkai penggalan berbagai film, dengan mengabaikan urutan tahun dan pengelompokan topik, tetapi dengan menambahkan sonor (bingkai suara) dalam rangkaian gambar itu. Sebagaimana disebutnya sendiri, sineas sadar bahwa representasi tidak pernah netral dan bebas nilai. ${ }^{15} \mathrm{MD}$ adalah film hasil kreasinya merangkai penggalan film-film Hindia-Belanda. Meskipun Monnikendam berupaya mempertahankan kepolosan dan kegamblangan yang disebutnya ada dalam film-film dasar itu, dia juga menyadari pandangan dan teknik pengolahan yang dia lakukan pada akhirnya mempengaruhi penyajian film-film itu dalam MD. Publik penonton yang menjadi kelompok sasarannya, meskipun tidak dirincinya lebih lanjut, dipastikan pertama-tama adalah penonton dari kalangan masyarakat Belanda dan Indonesia. Hal yang logis karena yang terlibat dalam wacana kolonial adalah Belanda sebagai pemerintah penguasa dan Indonesia sebagai masyarakat pribumi pada waktu itu. Hal itu lebih ditegaskan dengan disertakannya tembang dan puisi, sebagai sonor, yang disenandungkan dalam bahasa Indonesia, Jawa, Sunda, dan Nias dengan teks terjemahan sebagai subtitle dalam bahasa Inggris. Ada beberapa di antaranya tanpa disertai teks terjemahannya. Dengan teks terjemahan dalam

15 Monnikendam 1993: 9. 
bahasa Inggris dan demikian pula perubahan judul film ke bahasa Inggris (Mother Dao, the turtlelike) yang semula dalam bahasa Belanda (Moeder Dao, de schilpadgelijkende), menjadikan film itu selanjutnya lebih terbuka bagi umum yang ingin mengetahui wacana kolonial.

Dengan tidak menghadirkan teks terjemahan untuk suatu puisi, sineas sepertinya berusaha menghadirkan 'suara' Indonesia. Dengan demikian, metafora yang tercipta dalam melihat gambar dan bersamaan itu mendengar 'suara' seolah bukan datang dari dirinya, bukan pula interpretasinya, tetapi pandangan orang Indonesia. Dia memanfaatkan puisi itu untuk menyatakan bahwa dirinya tidak sendirian. Dalam hal ini, dapat diartikan bahwa selain menyatakan diri sebagai pengujar kritis yang anti-kolonial, sineas seolah juga menempatkan dirinya sebagai 'juru bicara' Indonesia.

Film-film dokumenter Hindia-Belanda yang kesemuanya bisu itu dirangkai menurut kisi-kisi logika tertentu dari Monnikendam dengan maksud juga untuk menciptakan efek-efek yang tidak akan diperoleh ketika menonton film-film dasar itu sendiri. Rangkaian yang tidak berpatokan pada waktu pembuatan film dan topiknya, tetapi kemudian dibubuhi sonor itu menayangkan perca-perca gambaran Hindia-Belanda. Meskipun penuturan gambar seolah-olah mengesankan acak, pemilihan jenis sonor seiring dengan gambar tertentu mengindikasikan upaya sineas membangkitkan efek-efek tertentu. Bukannya tidak disengaja jika suara adzan dipadukan dengan latar belakang musik gregorian mengiringi adegan pembaptisan yang dilakukan seorang pastor. Perca-perca gambaran di Hindia-Belanda yang tidak runut waktu, tempat, kejadian, dan topik itu disiratkan oleh Monnikendam sebagai upayanya untuk menunjukkan juga keragaman budaya, etnik, dan geografi Hindia-Belanda yang sulit terekam dalam sekali penayangan gambar.

Bagi sejumlah penonton Belanda, penggalan film-film Hindia-Belanda yang terangkai dalam film MD dapat membingungkan. Mereka itu pada umumnya percaya bahwa semboyan 'di sana (di Hindia) suatu karya atau pekerjaan yang besar sedang dilakukan' itu benar adanya karena sejarah yang mereka kenal, pelajari, dan cerita yang mereka dengar, menyatakan hal itu. Sineas Monnikendam mencermati film-film Hindia-Belanda itu dan kemudian memberikan "tuntunan" untuk melihat kembali wacana kolonial di masa lalu. Film-film Hindia-Belanda itu menurut Monnikendam mengungkap apa yang selama ini tak diketahui atau disadari atau luput diperhatikan baik oleh masyarakat modern Belanda maupun oleh masyarakat modern Indonesia, oleh generasi yang mengetahui wacana kolonial hanya dari sejarah dan cerita.

Publik Belanda sebagiannya menyebut isi MD sebagai 'kebusukan'16 yang harus dipahami oleh semua anggota masyarakat, seberapapun memalukan dan menyakitkannya. Rekaman keadaan sebagaimana adanya itu dalam pembacaan kembali justru mengungkap secara jelas hubungan kolonial yang ada antara Eropa yang berkuasa dan pribumi yang dikuasai: orang Eropa berpakaian lengkap serba putih, kontras dengan pribumi yang bertelanjang dada dan tanpa sepatu (lihat Gambar 2). Hubungan kolonial yang pada zamannya dilihat sebagai sesuatu yang sewajarnya (penguasa/penjajah

16 Terjemahan dari de rotzooi, istilah yang dipakai Maas dalam artikelnya (1995). 
versus yang dikuasai/dijajah), melalui kacamata masa kini dipahami kembali sebagai 'luka' oleh orang Indonesia. Kedua bangsa memang telah berdamai dan hidup sejajar, meskipun demikian mengkaji kembali teks kolonial itu tetap dilihat dan dirasa sebagai 'menoreh luka'. Reaksi yang muncul di media atas pemutaran MD mengesankan adanya amarah akan kejadian di masa kolonial. Walaupun demikian, ulasan yang ada di beberapa media Jakarta tidak sepenuhnya negatif. Ada yang menyambut baik pembuatan film itu dan mengartikannya sebagai pertanda niat baik Belanda menghargai penduduk negeri bekas koloni, sekaligus suatu bentuk penyesalan. Setidaknya dianggap ada upaya dari pihak Belanda untuk mengkaji kembali apa yang telah dilakukan leluhurnya, melihat dengan kritis dokumen kolonial. Walaupun tidak memperlihatkan friksi politik atau peperangan fisik, namun kontras antara kehidupan pribumi dan Eropa yang muncul dari penataan ulang gambar mampu memperlihatkan relasi kuasa yang ada pada waktu itu. Perpindahan yang cepat dari satu gambar ke gambar lain, ditambah dengan penataan sonor dan narasi yang unik ${ }^{17}$ dalam MD mengajak penonton untuk berpikir tentang apa yang dilihatnya. Jika publik Belanda kemudian tergugah untuk merasa malu dan harus meminta maaf atas 'kekhilafan kolonial' itu, publik Indonesia melihat diri sebagai pihak yang tanpa daya.

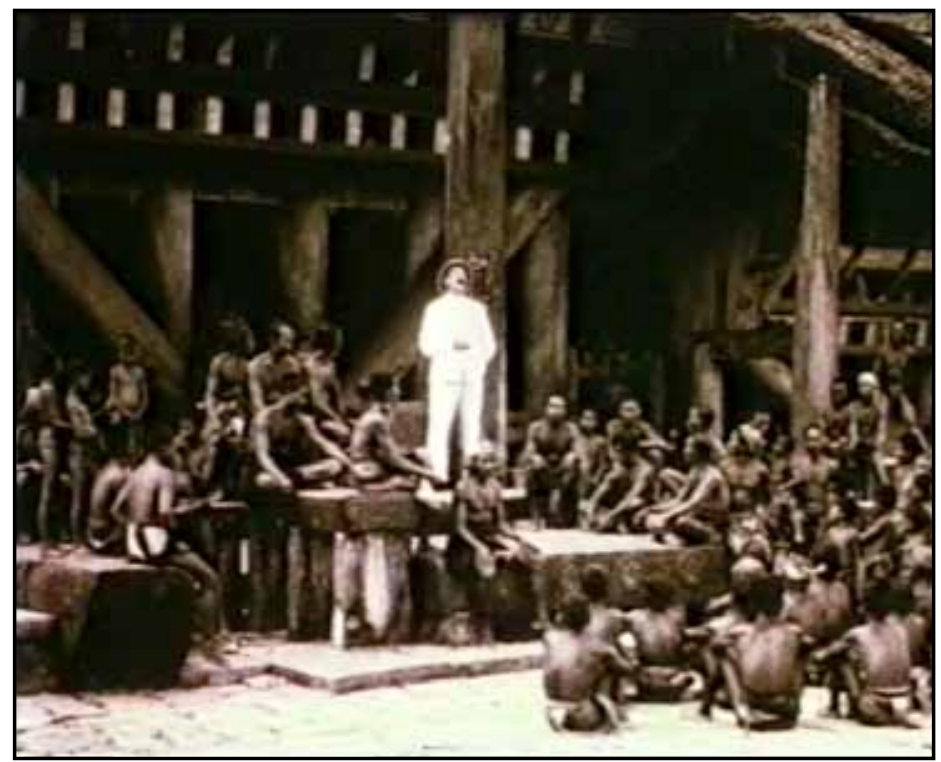

Gambar 2: Seorang pejabat penguasa berpidato di depan penduduk Nias.

Secara kebetulan MD diputar perdana tahun 1995, bersamaan dengan ulang tahun emas kemerdekaan Indonesia pada tanggal 17 Agustus dan saat kunjungan Ratu Beatrix ke Indonesia pada tanggal 21 Agustus. Diskusi yang

$17 \quad$ Narasi dalam film dokumenter seyogyanya memberikan komentar atau penjelasan pada gambar tetapi narasi dalam MD dipakai sebagai latar yang memberi suasana dan menggugah hati. 
kemudian berkembang adalah kaitan film ini dengan pengakuan Belanda atas 17 Agustus 1945 sebagai hari kemerdekaan Indonesia. Film yang mendapat sejumlah penghargaan ini, ${ }^{18}$ dalam pemutaran di pusat kebudayaan Belanda Erasmus Huis di Jakarta, tidak mendapat sambutan sebesar di Belanda. Ulasan pers Indonesia antara lain bertajuk "Belanda harus minta maaf" (Bakarudin 1995b), dan Massardi (1995: 69) menulis "Benarkah masa lalu adalah milik Tuhan, dan generasi baru tak perlu terusik dan mengecam? [...], film dokumenter ini menorehkan kembali sebuah luka lama".

Teks kolonial yang dipahami oleh sineas 'barat', diinterpretasikan berlainan oleh penonton Belanda dan Indonesia. Bagi penonton Belanda, MD adalah representasi dari interpretasi itu dan merupakan bentuk upaya etik untuk memperbaiki kesalahan; suatu langkah untuk meminta maaf. Lain halnya dengan penonton Indonesia. Kebijakan etik pemerintah kolonial, yaitu upaya untuk mengentaskan pribumi, dan upaya etik sutradara, yaitu menyesali apa yang terjadi, dipahami sebagai 'menoreh luka lama' dan 'penghormatan pada Hindia-Belanda' ${ }^{19}$ Politik etik yang mengubah kebijakan 'menimba untung' menjadi 'balas budi', dapat diinterpretasikan sebagai suatu kebijakan yang bertumpu pada pandangan bahwa subjek kolonial, yaitu mereka yang di bawah kekuasaan, secara rasial lebih rendah derajatnya. Salah satu sektor dalam kebijakan etik adalah memberikan pendidikan pada kaum pribumi. Namun, kebijakan itu dianggap tidak berarti karena sekolahsekolah di Hindia-Belanda tetap mempertahankan pemilahan berdasar ras, golongan, dan agama. Tetap ada perbedaan perlakuan atas orang Eropa dan pribumi. Seorang pribumi, meskipun telah mendapat pendidikan Barat dan menjadi Kristen, tetap merupakan subjek kolonial sehingga tidak akan pernah mendapat perlakuan yang sama dengan orang Eropa.

MD adalah hasil interpretasi Monnikendam atas film-film dokumenter Hindia-Belanda, yang menurutnya merepresentasikan hubungan kolonial. Rangkaian sekuen yang dipilih dan disusun cermat, serta diberi sonor (bingkai suara dan narasi) yang tampak menyampaikan ideologi dan nilai-nilai yang dianut sutradara. Seperti yang telah disinggung sedikit sebelumnya, hubungan kolonial dapat dilihat jelas dalam MD melalui oposisi: orang Eropa yang berkulit putih dan berpakaian serba putih versus kuli yang bertelanjang dada; yang satu memberi perintah versus yang lain berkeringat bekerja; sebuah kapal besar milik penguasa sedang melaju di sungai Barito versus perahu-perahu kecil mengiringi; kapal itu begitu besar, terbuat dari baja dan bertenaga mesin, dan muncul di tengah layar versus sampan itu kecil, dari kayu dan di dayung. Oposisi antara penguasa dan yang dikuasai juga tampak jelas misalnya dalam gambar kegiatan perusahaan pertambangan dan pembukaan lahan perkebunan. Hubungan kolonial yang kontras itu dapat disaksikan dari awal hingga akhir film dan seringkali dipertegas oleh penataan sonor dan narasi.

18 Di antaranya adalah: Gouden Kalf, hadiah utama di Nederlands Film Festival; Grand Prix Vue sur le docs, Marseille, Prancis; dan Grand Prix Golden Centaur, International Film Festival, St. Petersburg, Rusia.

19 Bianpoen 1995. 


\section{ANALISIS FILM MOEDER DAO, DE SCHILDPADGELIJKENDE}

Film ini menurut Monnikendam (1992: 11) disusun mengikuti tiga garis alur, yaitu (1) garis alur lansekap Hindia-Belanda, (2) Hindia-Belanda sebagai pemasok devisa Belanda, dan (3) kehidupan sosial di wilayah Hindia-Belanda itu. Dalam MD, sekuen-sekuen yang bercerita tentang kehidupan kuli tampak paling menonjol dengan adegan yang setiap kali berulang dalam pelbagai shot. Selain tiga sekuen yang bertajuk kuli, yaitu shot 19a-y, shot 44a-j, dan shot 51a-g, berbagai sekuen juga memuat dinamika kehidupan kuli, seperti terlihat dalam sekuen 6 (penebangan hutan), 8 (tambang minyak), 21 dan 24 (penebangan hutan dan penyiapan lahan perkebunan), 27 (panen tembakau), 30 (pabrik kaleng), 36 (pengolahan kapuk), 39 (pabrik gula), dan 50 (industri dan bengkel lokomotif). ${ }^{20}$ Dalam sejumlah sekuen itu penonton bukan hanya dapat menyaksikan kegiatan para kuli di lingkungan kerjanya, tetapi juga posisi mereka di lingkungan kerja itu dan hubungan mereka dengan para pejabat atasannya.

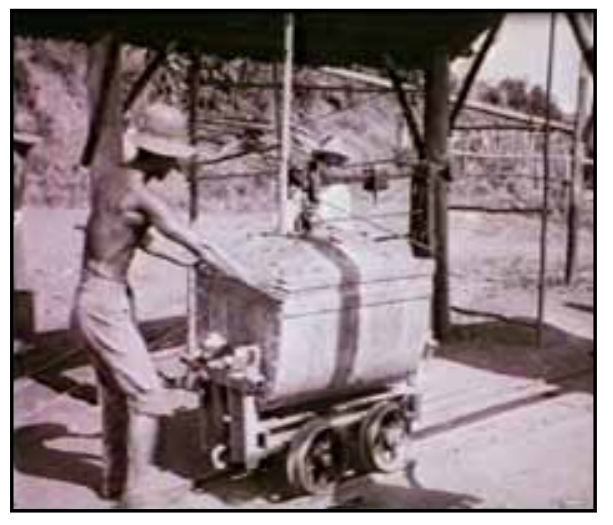

Gambar 3a: Kuli dengan lori di jembatan timbang, Tambang Timah Biliton.

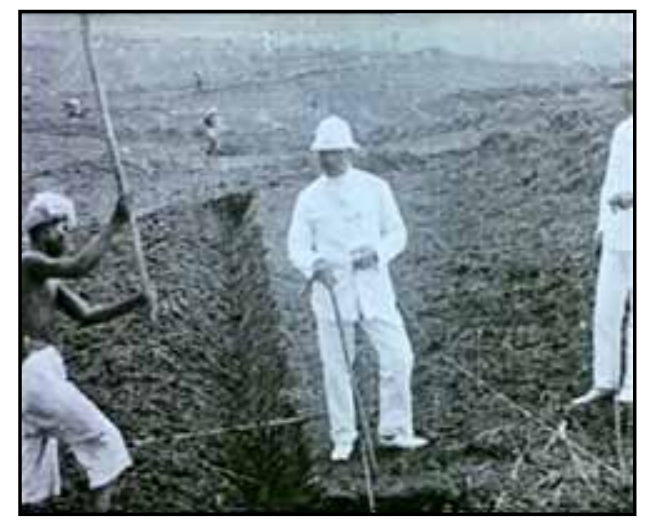

Gambar 3b: Seorang mandor sedang mengawasi kuli di Perkebunan Tembakau Klaten.

Sekuen-sekuen tersebut memperlihatkan berbagai kontras, yaitu kontras antara manusia dan mesin, manusia dan alam, serta bawahan dan atasan. Gambaran kuli menjadi bagian dari dekor pribumi dalam wacana kolonial yang ditampilkan dalam MD ini (lihat Gambar 3a dan 3b). Gambaran ini muncul terutama dalam ketiga sekuen yang bertajuk kuli $(19,44$, dan 51) yang akan diuraikan kemudian dalam tulisan ini. Sekuen 19 dan 44 berjudul sama "Kedatangan kuli" dan untuk sekuen 51 judulnya adalah "Selamatan dan penghargaan untuk kuli".

Seperti telah disebutkan sebelumnya, penggalan-penggalan film HindiaBelanda yang dijadikan dasar pembuatan MD itu bisu, tanpa bingkai suara. Dalam MD shot diiringi dalam bentuk voice-over ${ }^{21}$ seperti tembang dalam

\footnotetext{
$20 \quad$ Tentang judul-judul pelbagai sekuen lain lihat Lampiran.
}

${ }^{21}$ Narasi yang menindih gambar tanpa perlu terkait langsung dengan adegan sehingga isi narasi dan makna gambar bukan cerminan sama tapi dua hal yang memerlukan pemahaman bersama. 
bahasa daerah dan puisi yang dilantunkan dalam bahasa Indonesia. Hampir semua suara pengiring ini berasal dari karya Indonesia. Sebagian besar teks dalam bingkai suara ini dilengkapi dengan teks terjemahannya dalam bahasa Inggris yang tertera sebagai subtitle. Untuk beberapa bingkai suara yang dalam film itu tidak disertai dengan teks terjemahan Inggris, ada teks terjemahan Belandanya yang dapat dilihat dalam buku informasi tentang MD. Tidak semua penonton tentunya bisa memperoleh buku informasi itu. Selain itu, menonton film sambil mencari terjemahan dalam buku informasi pastilah hal yang tidak nyaman. Bagi penonton yang tidak mengerti bahasa Indonesia dengan baik, hal ini akan dapat mengganggu pemahaman baik keseluruhan maupun detil maksud MD. Alasan tanpa penyertaan teks terjemahan itu dapat saja karena kekurangtelitian sineas tetapi mungkin juga karena kesengajaan sineas. Kesengajaan yang dikaitkan dengan maksud menunjukkan perbedaan pokok antara film-film Hindia-Belanda yang menjadi bahan dasar dan MD itu sendiri. Yang 'berbicara' dalam film-film Hindia-Belanda yang bisu itu adalah penguasa (dan pribumi 'diam' mengikuti perintah), sedangkan dalam MD ‘suara Indonesia' diperdengarkan (dan yang lain 'diam'). Gambar dibiarkan diartikan menurut gambar itu sendiri dengan latar suara Indonesia. Untuk beberapa konteks, kadang-kadang bukan arti teks suara itu yang lebih berperan utama tetapi nada suara itulah yang membantu penonton dalam memahami dan menyerap makna gambar.

Sebelum sampai pada judul film, penonton pertama-tama dibawa menyaksikan wajah anak kecil dan letusan gunung Anak Krakatau. Sekuen ini disertai narasi yang menuturkan "Mitos penciptaan Nias, Ibu Dao" dalam bahasa Indonesia, yang dikutip oleh Monnikendam dari W.L. Steinhart (1934, Niassche teksten I en II). ${ }^{22}$ Narasi yang dibacakan lirih oleh suara perempuan Indonesia ini muncul dalam dua shot yang berbeda. Bagian pertama dari mitos berikut mengiringi shot $3 \mathrm{~d}-1$ :

Ketika bumi ini belum ada jagad raya belum tercipta hadir sudah ibu Dao kami senantiasa muda bak penyu.

Dikumpulkannya noda badan diurutnya di atas lutut diremasnya dengan telunjuk. Ketika dipandanginya berubahlah menjadi jagad, buana.
Ketika anak manusia belum terlahir pergilah ibu Dao kami ke kedalaman tak terhingga.

Dikumpulkannya arah mata angin.

Pada suatu hari

hamillah dia tanpa suami dibuahi tanpa pasangannya. Ketika musim panen berlalu lahirlah anak darinya diturunkannya kembar ke dunia seorang gadis, seorang jejaka. 
Narasi “Mitos penciptaan Nias" bagian kedua melatari shot 53b-g.

Pada suatu hari

suatu ketika

terlepaslah dari ibu Dao kami

yang senantiasa muda, bestari

ibu Dao kami yang bak penyu

rohnya melayang bersama angin

jiwanya menyisih bersama uap.

Pergilah dia dan berubah menjadi bumi menghilang menjadi debu.

Raganya mengisi segala celah abunya menjadi pengisi celahan bumi.
Keturunannya di bumi

anak-anaknya di jagad raya

menjadi tak terbilang bak debu dan butir

pasir

mereka berkembang biak

seperti padi sawilawa

namun mereka tak sadar

bahwasanya mereka seketurunan

mereka tak tahu bahwa mereka beradik kakak.

Sesudah judul, sejumlah shot ${ }^{23}$ silih berganti memperlihatkan berbagai pemandangan vulkan, sebuah kampung di Irian, pantai di pulau Biliton dan Sibolga, danau Toba, serta ritual korban di Flores. Babak pembuka itu sebagai prolog ditutup dengan bunyi letusan gunung, yang menyertai gambar kapal besar sedang merapat. ${ }^{24}$

Shot 19a- ${ }^{25}$ aslinya adalah montase dari dua film yang berbeda, yang pertama karya kinematograf ${ }^{26}$ I.A. Ochse tahun 1917 dan yang kedua dari kinematograf L.Ph. de Bussy tahun 1926-1928. Dalam shot itu terlihat sebuah kapal besar merapat di pelabuhan membawa para kuli dari Cina. Ada yang sedang berjongkok di dek kapal, makan, dan menjalani pemeriksaan kesehatan. Mereka kemudian dipindah ke kapal yang lebih kecil, dan berjalan menuju semacam tempat karantina berpagar kawat berduri. Selanjutnya terlihat pengukuran tinggi badan dilanjutkan dengan pembubuhan capjari sebagai bentukikatan kontrak. Adegan itu dilanjutkan dengan gambar yang memperlihatkan sejumlah kuli yang baru datang, di karantina, dan sedang mandi.

Sekuen 19 itu merekam kedatangan dan pencatatan kuli kontrak dari Cina ke perkebunan di Deli (lihat Gambar 4) dan mungkin juga perusahaan tambang di Biliton, sedangkan sekuen 44 bercerita tentang kedatangan kuli kontrak dari Jawa ke perkebunan. Dalam rombongan kuli dari Jawa terlihat perempuan dan anak-anak ikut serta. Sama halnya dengan sekuen 19, shot 44a-j adalah gabungan rekaman karya kinematograf Ochse (1917) dan De Bussy (1926).

Jika dalam sekuen 19 direkam adegan mandi dan penggundulan kepala, dalam sekuen 44 ini disertakan gambar pemeriksaan telinga. Pencatatan dactyloscopie seperti pengukuran tinggi badan, penantian giliran pemeriksaan kesehatan, tes darah, dapat ditemui dalam kedua sekuen, demikian pula adegan kuli di belakang kawat berduri yang satu persatu mendapat sesuatu, mungkin foto atau surat kontrak, kemudian makan sesuatu dari ransum di seputar barak. Perlakuan penguasa dalam kedua sekuen itu pada dasarnya sama, namun disampaikan dalam tindakan berbeda. Dalam sekuen 19

$23 \quad$ Lihat Bordwell dan Thompson 1993: 496.

24 Tentang pelbagai topik shot dapat dilihat dalam Lampiran.

25 Detil shot 19a-y lihat Lampiran.

26 Istilah yang dipakai pada waktu itu untuk menyebut pembuat film, yaitu sutradara yang sekaligus bertindak sebagai juru kamera. 
kesewenangan itu lebih terlihat pada saat pemeriksaan kesehatan, sedangkan dalam sekuen 44 hal itu terlihat dalam hardikan dan dorongan dengan kasar terhadap kuli yang sedang menunggu giliran pemeriksaan barang bawaan.

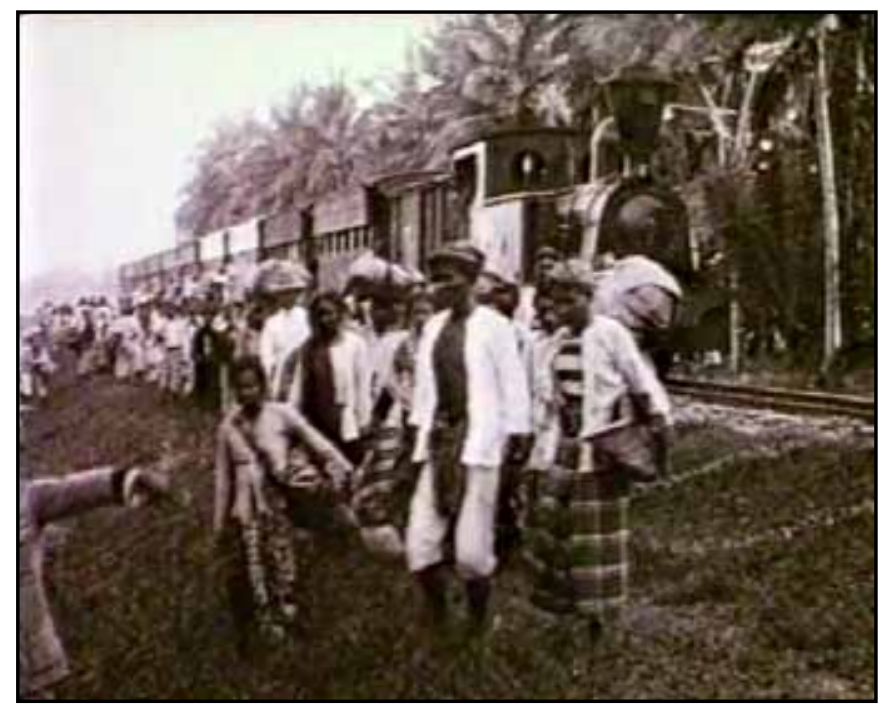

Gambar 4: Kedatangan kuli dari Jawa di Perkebunan Deli.

Ketika menyaksikan shot 19a-y itu penonton dapat melihat bagaimana penguasa pada waktu itu memperlakukan pekerjanya. Dalam film-film Hindia-Belanda sekuen tentang itu dipakai untuk menunjukkan rangkaian kegiatan yang dilakukan perusahaan tambang Biliton dalam mempersiapkan pekerja baru. Dalam rangkaian aslinya di film-film Hindia-Belanda semangat yang hendak ditonjolkan tentulah kecermatan dalam pengelolaan kesehatan. Namun, bagi penonton tahun 90-an sekuen yang memperlihatkan pagar kawat berduri itu mungkin saja akan dapat mengingatkan mereka pada kamp konsentrasi di Jerman pada Perang Dunia II daripada upaya etik perusahaan kolonial yang memperhatikan kesehatan pekerjanya. Bagi penonton Indonesia yang mungkin tidak akrab dengan ide kamp konsentrasi, perlakuan terhadap para pekerja seperti itu, dapat saja mengingatkan perlakuan manusia terhadap hewan ternak: menggiring ke dalam kandang, membersihkannya, memeriksa kesehatannya, dan menandainya/menomorinya.

Dalam pengambilan gambar dalam jarak menengah (medium shot) diperlihatkan sejumlah laki-laki sedang mandi, kecuali satu semua yang terlihat di layar dalam keadaan telanjang bulat, menghadap kamera. Gambar ini (dari shot 19) mungkin dimaksudkan sebagai contoh pendidikan kebersihan dan sanitasi. Kecanggungan mereka, terbukti dari usaha beberapa dari mereka untuk menutup bagian intimnya tidak dihiraukan oleh juru kamera. Kamera yang bergerak menyapu deretan orang mandi itu juga dapat diinterpretasikan sebagai tampilan nyata hubungan kekuasaan antara kinematograf Eropa dan subjek kolonial. Dapat dibayangkan bahwa kinematograf Eropa itu 
membuat film atas pesanan dan sesuai interpretasinya dia memberi petunjuk pada 'objek' rekaman bagaimana mereka harus bersikap di depan kamera. Berpegang pada permintaan pemesan, kinematograf berkuasa penuh atas apa yang harus direkamnya. Dia memperlakukan manusia di depan kamera, dalam hal ini kuli, semata-mata sebagai objek yang harus memenuhi daftar rekamannya.

Adegan penggundulan kepala dalam shot $19 \mathrm{u}-\mathrm{v}$ dapat diinterpretasikan sebagai bentuk dehumanisasi yang lain. Penggundulan kepala dalam filmfilm Hindia-Belanda pada waktu itu mungkin saja menjadi bagian dari pendidikan kesehatan karena banyak orang mengidap kutu. Penggundulan kepala merupakan cara untuk menghindari kemungkinan mengidap kutu. Penggundulan kepala juga dapat merupakan bagian dari prosedur baku penerimaan pekerja baru. Kepala yang gundul adalah identitas baru yang diberikan pada pekerja baru tanpa bisa ditolak. Dengan identitas baru itu mereka kemudian ditandai sebagai 'milik' perusahaan.

Dalam sekuen 19, pada adegan pengukuran tinggi badan terlihat petugas yang bersepatu menendang kaki pekerja yang sedang diukur karena pekerja tidak cukup merapatkan kakinya ke mistar. Perbuatan itu dalam bingkai (frame) lama dapat dilihat sebagai kecermatan kerja, karena kaki yang tidak merapat ke mistar dapat mempengaruhi ukuran tinggi badan. Namun, dalam bingkai baru, kaki bersepatu yang menendang kaki yang tidak bersepatu cukup memperlihatkan relasi kuasa yang ada. Pekerja yang mungkin tidak tahu sama sekali tentang semua sistem katalogisasi itu, pastilah juga tidak paham mengapa tinggi badannya harus diukur dan untuk itu kakinya harus rapat sejajar mistar. Pekerja tersebut pastilah juga tidak menyadari bahwa dirinya hanyalah nomor dalam sistem katalog itu. Dalam adegan ini sonor dapat dimaknai sebagai pengakuan sineas perihal perlakuan tidak manusiawi itu. Namun, penonton Indonesia mungkin saja memaknai lain, sebab petugas yang terlihat di gambar adalah orang sebangsa yang juga berpakaian putih, seperti kebiasaan pejabat kolonial Belanda waktu itu. Pakaian putih itu, dengan demikian, adalah representasi dari penguasa, baik secara harafiah maupun kiasan. Dengan memberi pakaian putih dan menyuruh melakukan sesuatu atas nama mereka sebagai penguasa, sama halnya menjadikan mereka perpanjangan tangan, dan dengan begitu mereka dapat mencuci tangan dengan cara bersembunyi di balik para pekerja bumi putera. Sekuen itu kiranya dapat diinterpretasikan sebagai bentuk kritik bukan saja terhadap tindakan kolonial Belanda tetapi juga terhadap tindakan semena-mena penguasa yang melempar batu sembunyi tangan. Di sisi lain, hal itu dapat pula diinterpretasikan sebagai pencarian kambing hitam. Sineas melihat bahwa bukan bangsa Belanda yang melakukan tindak tidak manusiawi, tetapi orang Indonesia sendiri. Pilihan gambar yang tentunya beralasan. Kenyataan ditampilkan apa adanya di sini dengan penonton dibiarkan membentuk persepsinya sendiri.

Dalam sekuen 19 itu dipakai puisi Rendra 'Sajak burung gagak' sebagai latar suara yang dilantunkan oleh suara lirih perempuan Indonesia. Bingkai suara ini muncul dalam shot 19d-o. 
Kelaparan adalah burung gagak yang licik dan hitam. Jutaan burung gagak bagai awan yang hitam Oh Allah!

Burung gagak menakutkan.

Kelaparan adalah burung gagak selalu menakutkan.

Kelaparan adalah pemberontakan.

Adalah penggerak gaib

pisau para pembunuh

yang diayunkan para miskin.

Kelaparan adalah batu-batu karang

Di balik laut yang tenang.

Adalah sumber penipuan.

Adalah pengkhianatan penghormatan.

Kelaparan adalah setan yang memuja

diktatur.

Oh Allah!
Kelaparan adalah tangan-tangan hitam

yang menjejalkan tawas di perut para miskin.

Oh Allah!

Kami bersujud.

Mata kami adalah matamu.

Ini juga mulut-Mu.

Ini juga hati-Mu.

Dan ini juga perut-Mu.

Kelaparan adalah burung gagak.

Jutaan burung gagak

bagai awan hitam

menutupi pandangan

ke surga-Mu!

Sebagai hasil pensejajaran gambar dan latar (baik nada suara maupun isi sajak) yang sepadan, maka kontras yang ada antara penguasa dan yang dikuasai lebih menggugah hati ketika puisi Rendra itu dilantunkan. Lantunan itu diawali dengan bunyi letusan gunung. Metafora burung gagak yang dipakai untuk mengacu penguasa kolonial dipertentangkan dengan 'para miskin' dan kelaparan, yang merupakan metafora para kuli dan pribumi pada umumnya.

Penggunaan sajak karya penyair Indonesia itu dapat dilihat sebagai upaya sineas untuk menghadirkan visi Indonesia, atau yang diperkirakannya sebagai reaksi Indonesia ketika menyaksikan adegan ini. Di sisi lain, puisi yang bertutur tentang doa orang lapar itu sebagai pilihan sineas, dapat dimaknai sebagai ungkapan penyesalan (sineas) Belanda atas apa yang terjadi. Menilik isi sajak yang begitu mengenaskan, di mana kelaparan disamakan dengan pisau pembunuh, batu karang di balik laut tenang, sumber penipuan, pengkhianatan kehormatan, setan, diktator, burung gagak, dan tangan hitam yang menjejalkan tawas di perut para miskin, maka penyesalan itu mengacu pada kebiadaban bangsanya. Terlebih jika diingat bahwa komentar dalam film dokumenter adalah suara sineas sendiri sebagai pengujar.

Dalam shot 44a-j tampak gambaran kekuasaan melalui penampilan para petugas yang berpakaian lengkap dan layak, sedang para calon pekerja terlihat lusuh dan berpakaian seadanya. Perjalanan panjang yang ditempuh mereka, terbukti dari kapal samudra besar yang mengangkut mereka, pastilah melelahkan dan siapa tahu perlakuan tak manusiawi sudah dimulai di sana. Mereka tidak beralas kaki dan membawa beban bawaan. Beberapa di antara pekerja sambil menggendong atau menuntun anaknya. Suatu pemandangan yang sangat kontras dengan para petugas yang berdiri tegak tanpa beban atau duduk nyaman sambil menjalankan tugas. Terlihat di layar petugas (pribumi) berdiri mengawasi para pekerja yang berjongkok, atau petugas pencatat yang 
duduk, sedang para pekerja yang harus membubuhkan cap jarinya berdiri. Jumlah pekerja yang begitu banyak juga memaksa mereka berdesakan dan harus berebut meminta perhatian petugas. Menjulurkan tangan melalui pagar kawat berduri sambil meneriakkan sesuatu, mereka berusaha melepaskan diri dari kelompok, tampil sebagai diri dan bukan satu dari deretan nomor. Dalam shot ini terlihat adanya hierarki penguasa dan pekerja. Penguasa di sini tidak hanya terbatas pada orang kulit putih saja tapi juga petugas yang pribumi.

Pada sekuen 44 sonor yang terdengar mulai shot 44e adalah satu bait dari "Serat Kalatidha" gubahan Ranggawarsita, yang ditembangkan dalam bahasa Jawa. Terjemahannya dalam bahasa Indonesia sebagai berikut: ${ }^{27}$

Rajanya paling mulia, patihnya berpikiran maju, para menterinya berwatak kokoh, punggawanya pemberani, namun tak berdaya menangkal, derita yang mengungkung, kian hari kian bertambah. Semua hanya berjuang, demi kepentingan sendiri. Lain halnya bagi yang perkasa, yang mendapat berkat dari Tuhan, tak perduli apa yang menimpa, mereka tak meraih untung. Didapatnya berkat kebajikan, bukankah Tuhan memberi pertolongan. Melalui sesamanya, dalam bentuk karya berguna. Namun mereka tetap melakukan yang terbaik.

Apa yang terutama terungkap dari bait tembang itu adalah penyesalan akan semakin buruknya keadaan dan ajakan agar orang tidak senantiasa memikirkan keuntungan. Bait tembang itu juga mengungkap ketidakmengertian aku lirik, sebab meskipun para penguasa berlaku baik, namun keadaan tetap saja memburuk. Memburuknya keadaan kiranya bukan karena perilaku penguasa, namun karena orang saling bertikai dan memikirkan kepentingannya sendiri. Nasib buruk yang menimpa para pekerja kontrak itu dijalin berdasarkan shot, dari tahun pembuatan yang cukup jauh jaraknya. Dengan bingkai suara hal itu semakin tegas bahwa memang keadaan tidak menjadi lebih baik. Adegan awal yang memperlihatkan barisan pekerja, laki-laki, perempuan, dan anakanak, seakan-akan menyampaikan bahwa sesudah sekian tahun keadaan masih tetap sama, bahkan mungkin semakin banyak orang yang memilih menjadi pekerja kontrak, meski harus meninggalkan keluarga. Jika pada shot berikutnya, produksi tahun 1917, terlihat hanya laki-laki yang menjadi pekerja, beberapa tahun kemudian, pada tahun 1926, bahkan perempuan dan anak-anak pun harus ikut serta.

Sekuen 51 menampilkan kuli dalam wajah berbeda. Shot 51a-g itu bercerita tentang pesta panen tebu dan pemberian penghargaan terhadap tiga orang pekerja kontrak yang telah setia mengabdi. Sekuen ini dibuka dengan gambar meja makan panjang yang tertata rapi. Sesudah adegan pembuka itu terlihat gambar seorang perempuan Eropa, didampingi seorang laki-laki, menyematkan bintang, menyerahkan piagam, dan kemudian mengalungkan bunga pada seorang pekerja. Adegan itu ditutup dengan pengangkatan gelas

27 Diterjemahkan oleh Jugiarie Soegiarto. 
berisi champagne. Tiga orang pekerja yang memperoleh penghargaan terlihat beberapa kali bersulang dengan berbagai petinggi perusahaan, sebelum mengarahkan diri menghadap ke kamera dan ke hadirin pengunjung pesta. Sekuen ini diakhiri dengan adegan penyulutan kembang api oleh beberapa pekerja dan ditutup dengan lagu "Liwung", lagu cinta dari daerah Sunda, dalam bahasa Sunda, pada shot 51b-g dengan terjemahan dalam bahasa Indonesia sebagai berikut: ${ }^{28}$

$\begin{array}{ll}\text { Bulan, tunjukkanlah cahaya terangmu, } & \text { jatuh cinta seperti terkena sihir } \\ \text { tampakkanlah dirimu } & \text { kini ingin melihat bulan punama } \\ \text { jangan bersembunyi di balik awan } & \text { berjalan-jalan mencari makna } \\ \text { kasihanilah aku } & \text { berharap dapat melipur } \\ \text { yang bingung penuh pikiran } & \text { berpaling memikirkan sesuatu. }\end{array}$

Perbedaan yang segera tampak dalam sekuen ini (51) dibanding dua sekuen tersebut di atas (19 dan 44) adalah bahwa dalam sekuen ini kuli tidak ditempatkan di lingkungan kerjanya atau tidak sedang bekerja. Mereka berdiri sejajar dengan orang Eropa atasannya, mengenakan pakaian pesta, dan mendapat penghargaan. Namun demikian, apa yang menarik dalam sekuen ini adalah adegan bersulang, yang nampak canggung dilakukan para pekerja penerima penghargaan. Bingkai suara juga berbeda, tidak sebagaimana dua sekuen tentang kuli sebelumnya, pada sekuen ini diiringi dengan lagu cinta. Menilik adegan yang terlihat di gambar lagu cinta itu terlihat menjadi bingkai yang senada dengan isi gambar. Jika sonor dapat diinterpretasikan sebagai penegasan sineas atas pemahamannya terhadap gambar, maka lagu cinta itu kiranya dimaksudkan sebagai cerminan dua pihak yang berbagi kasih.

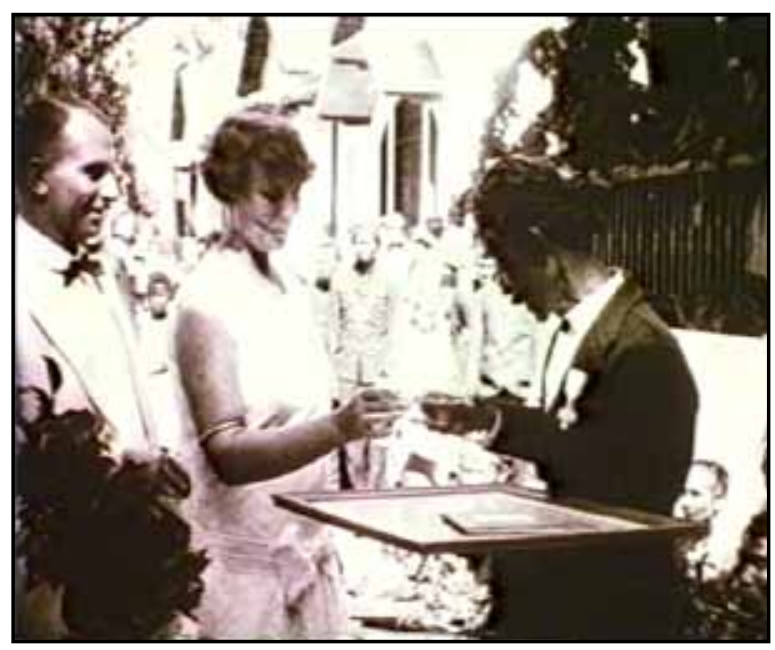

Gambar 5: Seorang pekerja kontrak bersulang saat menerima penghargaan (Pabrik Gula Jawa Timur). 
Di dalam gambar (lihat Gambar 5) terlihat bahwa adegan bersulang itu tertuju pada para pejabat Eropa, dan tidak sekalipun tertuju pada para pekerja lain yang juga ikut menghadiri pesta itu. Penerima penghargaan itu tampak bersikap kikuk, dan hal itu telah terlihat sejak penyematan bintang dan penerimaan piagam. Sebelum pengalungan bunga, pekerja itu tampak kebingungan karena tangannya sudah memegang piagam sementara dia masih harus menerima gelas dan, mungkin, berjabat tangan. Kecanggungan itu juga terlihat pada adegan bersulang. Pejabat Eropa yang terlihat di gambar setiap kali mendahului seolah-olah memberi contoh. Para pekerja itupun setiap kali tampak tidak tahu harus menghadap ke arah mana, atau ke siapa.

Kecanggungan yang tampak dalam gambar kiranya dapat diterangkan sebagai kecanggungan kuli menghadapi kebiasaan yang berbeda. Bagi pekerja kontrak, bekerja adalah upaya pemenuhan kebutuhan hidup. Menjadi pekerja kontrak sangat mungkin bukanlah pilihan pertama, karena hal itu berarti meninggalkan kampung halaman, terpisah dari keluarga, dan mengikatkan diri. Apa yang oleh perusahaan kemudian disebut sebagai 'kesetiaan mengabdi', atau mungkin sebagai cara mendorong agar pekerja itu makin rajin dan loyal atau agar para pekerja lain mengikuti jejak pekerja yang kali ini beruntung mendapat penghargaan itu. Dengan demikian, mungkin makin sulitlah bagi para pekerja untuk berhenti atau mencari pekerjaan lain, selain barangkali dari pihaknya tidak memiliki hak untuk memutuskan kontrak.

Hal lain yang membuat para pekerja canggung adalah berdiri berhadapan dengan orang Eropa dan menerima penghargaan dari seorang perempuan Eropa. Dalam kehidupan mereka yang sehari-hari orang Eropa itu adalah atasannya, yang memberi perintah atau menunjukkan satu dan lain hal. Di lingkungan kerja mereka dan atasan itu tidak berdiri sejajar, apalagi berhadapan, dan bersulang. Mendapatkan diri di tempat dan suasana yang sama sekali lain itu tentulah membingungkan mereka. Kebingungan itu masih ditambah lagi dengan kenyataan adanya seorang perempuan Eropa yang menyematkan bintang di dadanya. Perempuan, yang mungkin istri pejabat perusahaan, bukanlah bagian dari hal yang biasa dan tidak dikenal oleh pekerja tersebut dalam hubungan kerja. Dalam kesempatan itu seolah-olah secara tiba-tiba tokoh perempuan itu muncul dan mengambil peran berarti dalam konteks hubungan atasan dan bawahan.

Seperti yang diungkapkan dalam uraian di atas, kenyataan lain yang sangat mencolok dalam sekuen ini adalah adegan bersulang. Adegan ini bukan semata kegiatan minum bersama, tetapi kenyataan bahwa bersulang bukanlah bagian kebiasaan dari budaya para pekerja pribumi itu. Para pekerja itu mungkin mengenal dan bisa saja pernah minum minuman keras, tetapi tradisi bersulang sebagaimana yang dilakukan orang Eropa seperti halnya dengan kegiatan pemberian penghargaan, bukanlah bagian kebiasaan para kuli. Kecanggungan yang terjadi bukan hanya karena kenyataan bahwa mereka harus minum minuman beralkohol, tetapi lebih karena mereka harus memaknainya sesuai pemahaman Eropa. Para pekerja bukan saja harus minum sambil berdiri, tetapi bahwa mereka harus berdiri sejajar dengan atasannya, sementara teman-teman 
pekerja yang lain tetap duduk bersila di bawah.

Sekuen ini merupakan penggalan film Hindia-Belanda yang dibuat untuk memperlihatkan aktivitas kerja yang dilakukan orang-orang Belanda di Hindia-Belanda. Aktivitas kerja yang dilukiskan dan didengungkan sebagai pekerjaan besar dan penting yang dilakukan tanpa mengabaikan masyarakat pribumi di Hindia-Belanda, sesuai dengan kebijakan etik yang diterapkan pada waktu itu. Adegan pemberian penghargaan dan bersulang pada kenyataannya merupakan bagian "laporan" bagi negeri induk bahwa pengabdi pribumi yang bekerja keras untuk mereka sebagai penguasa di Hindia-Belanda tidak diabaikan. Namun, seperti yang dapat diamati dalam sekuen tentang pemberian penghargaan dan acara bersulang itu wacana kolonial tampak jelas. Kedudukan 'atasan sekaligus penguasa' versus 'bawahan pribumi' yang analoginya mengartikan 'yang memerintah dan menentukan' versus 'yang menjalankan/menerima perintah' sepertinya kala itu wajar sesuai dengan nilai dan norma kolonial. Budaya masyarakat pribumi tidak berarti dan juga tidak terpikir atau dipikirkan untuk menjadi bahan pertimbangan penyelenggaraan acara penguasa pada waktu itu. Penguasa hanya memikirkan kepentingan dan kesenangan mereka sendiri dan mendasarkan dirinya pada kebiasaan yang ada dalam budaya mereka. Pemberian penghargaan bagi pekerja yang mengabdi kepada mereka adalah selain tentunya demi untuk kepentingan mereka dalam upaya lebih mengikat loyalitas pekerja itu kepada mereka, juga seolah merupakan suatu pekerjaan yang mereka lakukan demi pekerja itu sendiri - tanda kebaikan yang mereka 'berikan' kepada masyarakat pribumi. Kecanggungan sikap pekerja dalam acara penghargaan dan bersulang yang terlihat dalam film Moeder Dao sekarang ini menegaskan hubungan penindas dan yang ditindas pada waktu itu. Pekerja hanya menjalankan apa yang diperintahkan, juga dalam acara pemberian penghargaan dan bersulang itu. Dapat dibayangkan, dalam konteks dan situasi kolonial yang sulit di saat itu suatu penghargaan hasil kerja dan kesempatan untuk lebih dekat dengan atasan yang sekaligus pemegang kuasa bagi seorang pekerja rendahan tentunya dan sewajarnya merupakan suatu pengalaman yang mungkin tidak nyaman tetapi bukan juga hal yang disesali, bahkan mungkin membanggakan. Justru hal yang terakhir inilah yang menjadi tujuan pihak penguasa: menstimulasi loyalitas dan produksi kerja. Dalam lagu "Liwung" sebagai bingkai suara dari sekuen ini diungkapkan bahwa aku lirik ingin mengendapkan pengalaman yang baru dilaluinya, sambil berharap semoga dirinya dapat berpaling dan tetap berpikir jernih.

Di samping puisi dan lagu yang sudah dibicarakan di atas, berikut dikemukakan pula puisi-puisi yang dapat diinterpretasikan sebagai pengiring yang tepat dan reaksi atas wacana kolonial. Puisi dengan makna yang tepat mengacu gambar dalam sekuen 50, misalnya puisi Amir Hamzah yang berjudul "Turun kembali" seperti berikut: 
Kalau aku dalam engkau

Kau dalam aku

Adakah begini jadinya

Aku hamba, engkau penghulu?

Dalam MD diperlihatkan pula beberapa kontras, bukan hanya antara penguasa dan yang dikuasai atau hubungan atasan dan bawahan tetapi juga kontras antara manusia dan mesin. Sejumlah shot di sekuen 50 sebagai rangkaian penggalan yang berasal dari karya empat kinematograf yang berbedabeda dibuat antara tahun 1924-1927,,$^{29}$ bercerita tentang berbagai kegiatan perindustrian, yaitu di pelabuhan, bengkel lokomotif, dan pertambangan minyak. Kontras yang ada antara para pekerja dan putaran mesin-mesin merupakan metafora manusia yang begitu ringkih dipertentangkan dengan lokomotif raksasa yang harus didorongnya. Kontras lain yang terlihat adalah perbandingan jumlah pekerja pribumi yang begitu besar yang kontras dengan beberapa gelintir pejabat Eropa yang menjadi atasan mereka. Selain itu, terlihat juga kontras dalam pakaian yang mereka kenakan. Para pejabat yang menjadi pimpinan dan memberi arahan, berpakaian serba putih dan lengkap, sementara para pekerja berpakaian lusuh seadanya. Puisi yang menjadi bingkai suara sangat pendek, bertutur tentang pengandaian akan pertukaran tempat. Puisi itu begitu jelas mengacu pada kedua kelompok manusia yang terlihat dalam gambar. Namun, angan-angan itu harus segera dilupakan, karena sebagaimana bunyi baris terakhir yang satu tetap hamba sedang yang lain penghulu. Aku di sini tentulah penduduk wilayah kolonial, sebab puisi ini dibacakan dalam bahasa Indonesia.

Yang menarik juga dalam MD ini adalah adanya puisi yang ditulis oleh Monnikendam sendiri, yang membingkai shot 52a-e dan dibacakan dalam bahasa Indonesia. ${ }^{30}$

Katakanlah pada mereka yang tak jauh dari sini:

pendopo dan alun-alun sudah

ditinggalkan

pohon beringin menebar kesejukan

menaungi mereka yang beristirahat abadi

dan yang berkeluh-kesah di semua benua katakanlah pada mereka yang tak jauh dari sini:

tentang semua yang jauh katakan semua sekali lagi sementara aku mendengarnya semua sekali lagi.

Isi puisi itu menyebarluaskan berita bahwa masa itu telah berlalu. Pendopo, alun-alun, dan pohon beringin dapat diinterpretasikan sebagai wilayah koloni, sedang mereka yang disebut sudah beristirahat abadi dan yang berkeluhkesah tentulah mereka yang berkaitan dengan masa kolonial, mereka yang sudah berdamai atau mereka yang masih belum dapat menerima kenyataan, bahwa masa kolonial telah berlalu. Dengan film ini penyair seakan mengajak penonton agar menyebarkan pemahamannya bahwa masa kejayaan kolonial itu telah berlalu, dan bahwa kenyataan itu harus diterima dengan rasa damai. Mereka yang diacu dalam puisi itu dapat diinterpretasikan sebagai orang

\footnotetext{
29 Lihat nama-nama kinematograf dalam Lampiran.

30 Penerjemah: Jugiarie Soegiarto.
} 
Belanda, sebab mereka itu adalah yang tidak jauh dari sini. Penyair yang juga sineas film ini jelas menggarisbawahi pesan yang hendak disampaikannya melalui rangkaian penggalan film Hindia-Belanda itu. Mereka yang tadinya terlibat dalam hubungan atasan-bawahan, atau yang menguasai dan yang dikuasai, sekarang hendaklah hidup dalam damai dan sebagai pihak-pihak pada tataran sejajar.

\section{PENUTUP}

Film Moeder Dao, de schilpadgelijkende diolah dari sejumlah film dokumenter Hindia-Belanda yang dibuat antara tahun 1912 dan kira-kira tahun 1933. Film-film Hindia-Belanda tersebut aslinya tanpa suara dan sebagai datanya hanya dilengkapi dengan teks yang berisi informasi waktu pemutaran. Vincent Monnikendam sebagai sineas tidak melakukan rekayasa gambar, dan untuk menyiasati gambar-gambar dalam film Hindia-Belanda yang dinilainya tidak memperlihatkan kehidupan sesungguhnya dari subjek kolonial, maka dia menambahkan sonor dalam film Moeder Dao itu. Cara merangkai penggalan film lama itu mampu menghadirkan wacana kritis kolonial dan mengajak penonton cermat dalam melihat relasi kuasa yang ada pada waktu itu. Bingkai suara yang ditambahkan menggarisbawahi interpretasi sineas tentang keadaan masa itu yang dinilainya timpang. Puisi yang ditambahkan, dua di antaranya ditulis oleh sineas sendiri, selain memperkuat dramatisasi, juga menegaskan pendapat sineas tentang kebijakan kolonial bangsanya.

Pada awal abad dua puluh kebijakan etik merupakan acuan yang kala itu mendasari pembuatan film-film kolonial yang diproduksi di HindiaBelanda. Film-film itu dibuat atas pesanan dengan fungsi untuk merekam karya dan pekerjaan-pekerjaan besar yang sedang dilakukan di HindiaBelanda. Sebelumnya, Hindia-Belanda di bawah semboyan liberal hanya menitikberatkan pencarian keuntungan, kemudian dengan cetusan kaum etik menjadikan Hindia-Belanda sebagai wilayah koloni yang harus dilindungi dan dikembangkan. Tiga pokok kebijakan etik adalah pengembangan di bidang irigasi, pendidikan, dan emigrasi. Kegiatan-kegiatan di ketiga sektor ini, yang bagi sudut pandang Belanda merupakan perbaikan dan pembangunan Hindia-Belanda sebagai perwujudan kebijakan etik, terekam dalam film-film Hindia-Belanda. Oleh karena itu, film-film Hindia-Belanda itu merepresentasikan Hindia-Belanda, merupakan suatu laporan ke negeri induk tentang apa yang dikerjakan oleh masyarakatnya di Hindia-Belanda. Film-film inilah yang dijadikan sebagai bahan dasar pembuatan film Moeder Dao, de schildpadgelijkende (1995) oleh Vincent Monnikendam. Meskipun film Moeder Dao berisi rangkaian penggalan film-film Hindia-Belanda itu, film Moeder Dao berkat olahan dan penataan sineasnya mampu mengajak para penontonnya untuk mengkaji kembali wacana kolonial di Hindia-Belanda. Melihat medium bahasa yang digunakan dalam sonor (dalam bentuk puisi, tembang, narasi) adalah bahasa Indonesia serta beberapa bahasa daerah di Indonesia, maka dapat dinyatakan bahwa publik yang menjadi sasaran utama tak lain tentunya adalah masyarakat Belanda dan Indonesia. Publik 
penonton pada tahun 90-an pada umumnya terdiri dari orang-orang yang mengenal wacana kolonial melalui sejarah dan cerita, bukan orang-orang yang mengalami masa kolonial. Untuk itu, sineas berupaya menampilkan kembali sejumlah gambaran wacana kolonial secara 'polos dan gamblang' kepada publik. Penerapan kebijakan etik di Hindia-Belanda yang dibanggakan pemerintah Belanda kala itu dalam film Moeder Dao itu lebih menegaskan relasi kuasa, diskriminasi, dan penindasan. Oposisi Eropa/Belanda sebagai penguasa dan pribumi sebagai yang dikuasai dengan segala dampaknya jelas terlihat. Oposisi ini juga terlihat di antaranya melalui simbol-simbol seperti warna putih versus bertelanjang dada, bersepatu versus bertelanjang kaki, dan berdiri dalam sikap tegap memerintah versus membungkuk/duduk bersila/ berjongkok di tanah. Penataan gambar yang aslinya bisu dan pilihan bingkai suara yang tepat membiarkan emosi penonton terbawa menuju persepsinya masing-masing.

Pemilihan puisi, tembang, dan narasi yang hampir semuanya Indonesia untuk bingkai suara dapat dilihat sebagai upaya sineas yang memberi kesempatan kali ini bagi Indonesia untuk 'berbicara'. 'Berbicara' mengiringi sesuatu yang telah terjadi di masa lampau ketika yang ada hanya ketakberdayaan sebagai 'yang dikuasai dan ditindas'. Pilihan bingkai suara dan isi teks yang dialunkan dalam nada kepedihan mengungkapkan kepiluan dari yang menjadi korban.

Kesengajaan sineas mensejajarkan hal-hal yang tidak sama dapat pula diinterpretasikan sebagai upayanya untuk memperlihatkan kesamaan dan sekaligus keberagaman, misalnya: suara adzan yang dikombinasikan dengan musik gregorian untuk mengiringi gambar suatu pembaptisan oleh pastor. Kesamaan, untuk menyadari bahwa manusia itu sama dan memiliki kebutuhan yang sama dalam beragama. Keberagaman, untuk menyadari bahwa respek dibutuhkan untuk menghargai pilihan masing-masing dalam menjalankan kepercayaannya. Sonor yang dipilih sineas dalam sekuensekuen tertentu seolah-olah tidak sinkron dengan gambar, sebenarnya justru merupakan kesengajaan sineas untuk membangkitkan efek tertentu dan untuk menegaskan keragaman yang tinggi dari budaya Indonesia.

Bagaimanapun teknik pembuatan film dan penyampaiannya, Monnikendam selain menerima sejumlah penghargaan akan filmnya itu tetapi juga kritik dan kecaman baik di negeri Belanda maupun Indonesia. Di Belanda ada yang berpendapat bahwa penggalan-penggalan film dasar itu dikeluarkan dari konteksnya dan pada masa sekarang tidaklah relevan lagi untuk ditampilkan secara baru dan bukan sebagai arsip. Di Indonesia ada yang beranggapan bahwa film Moeder Dao 'menoreh luka lama' tetapi juga ada yang berpendapat bahwa film itu memperlihatkan realitas kejadian di masa itu dan itu perlu disadari betapapun menyakitkan dan memalukan. Bagi yang diselubungi kemarahan, sineas melalui filmnya dianggap ingin memperlihatkan dan menegaskan kembali posisi superior yang pernah dimiliki oleh Belanda di masa kolonial. Bagaimanapun pujian dan kritikan yang ada, film Moeder Dao memperlihatkan kandungan nilai seni film tentang 
wacana kolonial yang perlu dan menarik untuk dikaji. Ragam reaksi dan kritik yang ada dapat dilihat sebagai tolok keberhasilan sineas dalam mencapai publik, karena film ini memang dimaksudkannya sebagai ajakan untuk mengkaji ulang politik kolonial. Film Moeder Dao, de schildpadgelijkende adalah suatu hasil kerja keras dari Monnikendam dalam menelusuri dan menyeleksi data yang berkilometer panjangnya, dan merupakan kreasinya yang ulung sebagai sineas yang berpengalaman.

\section{TEKS KAJIAN}

Moeder Dao, de schildpadgelijkende; Een kinematografische verbeelding van Nederlandsch-Indië1912 - ca. 1933 (Mother Dao, the turtlelike; A kinematographic image of the Dutch-Indies 1912 - ca. 1933).

Documentary composition: Vincent Monnikendam; editor: Licky Zydower, titles/graphic design: Ronald Vierbergen, Albert Markus; co-research and co-filmrestorater: Rogier Smeele; producer: Rade Milicevic; sound composition: Jan-Dries Groenendijk; kinematographers: Tassilo Adam, Piet beeltjens, Simon Buis, L.Ph. de Bussy, Ph.G. Carli, H.J. Flindt, Johan Lamster, H. Melman, Miller, Willy Mullens, Iep Ochse, Richard Peck, Hendrik Tillema, Willy Rach, Louis van Vuren, and unknown.

Koleksi: Het Nederlands Filmmuseum (NFM), Het NOS-Polygoon Archief (NOB-AVAC), De Rijks Voorlichtings Dienst (RVD).

Judul dan puisi tema: Moeder Dao, de schildpadgelijkende, diambil dari W.L. Steinhart (1934), Niassche teksten I en II.

\section{DAFTAR PUSTAKA}

Bakarudin. 1995a. "Merekam sejarah secara jujur; Film dokumenter HindiaBelanda tahun 1912-1932; Jujur, mencekam, dan penuh simbolisme", Tiras 12 (20 April): 72.

Bakarudin. 1995b. “ Wawancara Vincent Monnikendam: Pemerintah Belanda harus minta maaf", Tiras 12 (20 April): 73.

Bianpoen, Carla. 1995. "Dutch center pays homage to East Indies", The Jakarta Post (7 April): 7.

Bordwell, David dan Kristin Thompson. 1993. Film art; An introduction. New York: McGraw-Hill.

De Jong, J.J.P. 1998. De waaier van het fortuin; Van handelscompagnie tot koloniaal imperium; De Nederlanders in Azië en de Indonesische archipel 1595-1950. Den Haag: Sdu.

Hellwig, Tineke. 2007. Citra kaum perempuan di Hindia Belanda. Diterjemahkan oleh Mien Joebhaar. Jakarta: Yayasan Obor Indonesia. (Judul asli: Adjusment and discontent: representations of women in the Dutch East Indies, Winsor, Ontario: Netherlandic Press, 1994).

Maas, Cornald. 1995. "De rotzooi moet boven water komen", De Volkskrant (20 Januari): 12.

Maters, Mirjam. 2003. Dari perintah halus ke tindakan keras; Pers zaman kolonial antara kebebasan dan pemberangusan 1906-1942. Diterjemahkan oleh Mien Joebhaar. Jakarta: Hasta Mitra, Pustaka Utan Kayu, KITLV-Jakarta. (Judul 
asli Van zachte wenk tot harde hand; Persvrijheid en persbreidel in NederlandsIndië (1906-1942), Hilversum: Verloren, 1998).

Monnikendam, Vincent. 1992, “Indië - filmproject; Synopsis voor een documentaire". Hilversum: NOS, Afd. Culturele Programma's.

Monnikendam, Vincent. 1995, "Informatie, zangen en gedichten bij de documentaire Moeder Dao, de Schildpadgelijkende; Een kinematografishe verbeelding van Nederlandsch-Indië 1912-ca.1933. Hilversum: Nederlandse Programma Stichting.

Naeff, Frans, (red.). 1978. Het aanzien Indië; Herinneringen aan een koloniaal verleden. Amsterdam: Het Spectrum.

Steinhart, W.L. 1934. Niassche teksten. Bandoeng: Nix. (Bataviaasch Genootschap van Kunsten en Wetenschappen 73).

Van Doorn, J.A.A. 1994. De laatste eeuw van Indië: ontwikkeling en ondergang van een koloniaal project. Amsterdam: Bert Bakker.

Van Helsdingen, Mr. W.H. 1941. Daar wèrd wat groots verricht [...]: NederlandschIndië in de XXste eeuw. Amsterdam: Elsevier.

Williams, Patrick dan Laura Chrisman. 1993. Colonial discourse and post-colonial theory: a reader. New York: Harvester Wheatsheaf.

\section{LAMPIRAN}

Daftar judul sekuen dan shot (diringkas dan diterjemahkan dari Monnikendam 1995)

\begin{tabular}{|l|l|l|l|l|}
\hline $\begin{array}{c}\text { Nomor } \\
\text { urut shot }\end{array}$ & $\begin{array}{c}\text { Tahun } \\
\text { pembuatan }\end{array}$ & $\begin{array}{c}\text { Nama } \\
\text { kinematograf }\end{array}$ & \multicolumn{1}{|c|}{ Judul sekuen } & \multicolumn{1}{|c|}{ Keterangan gambar } \\
\hline 1 & $1926-1928$ & Iep Ochse & Anak laki-laki bertopi & $\begin{array}{l}\text { Anak kecil bertopi, murid sekolah } \\
\text { desa Tlepok, Jawa Tengah }\end{array}$ \\
\hline 2a & & $\begin{array}{l}\text { Judul: Moeder Dao, } \\
\text { de schildpadgelijkende/ } \\
\text { Mother Dao, the } \\
\text { turtlelike }\end{array}$ & $\begin{array}{l}\text { Moeder Dao, de } \\
\text { schildpadgelijkende }\end{array}$ \\
\hline 2b & & & & $\begin{array}{l}\text { Een kinematografische verbeelding } \\
\text { van Nederlandsch-Indië van } \\
\text { 1912-ca. 1933 door Vincent } \\
\text { Monnikendam }\end{array}$ \\
\hline $3 \mathrm{a}-\mathrm{c}$ & 1929 & Iep Ochse & Prolog & $\begin{array}{l}\text { Letusan gunung Anak Krakatau, } \\
\text { Selat Sunda }\end{array}$ \\
\hline 3d/e & 1927 & Willy Mullens & & Pemandangan vulkan di Bandung \\
\hline 3f & 1929 & Iep Ochse & & Gunung Papandayan, Garut \\
\hline $3 \mathrm{~g}$ & 1928 & Iep Ochse & & $\begin{array}{l}\text { Orang berjalan di sekitar kawah } \\
\text { Kamojang, Garut }\end{array}$ \\
\hline 3h/i & 1926 & Richard Peck & & Kampung di pegunungan Papua \\
\hline $3 \mathrm{j}$ & 1926 & Iep Ochse & & Pantai dan karang Biliton \\
\hline $3 \mathrm{k}$ & 1927 & Iep Ochse & & Kerbau di pinggir Danau Toba \\
\hline $3 \mathrm{l}$ & 1927 & Iep Ochse & & Anak kecil di pantai Sibolga \\
\hline
\end{tabular}




\begin{tabular}{|c|c|c|c|c|}
\hline $\begin{array}{l}\text { Nomor } \\
\text { urut shot }\end{array}$ & $\begin{array}{c}\text { Tahun } \\
\text { pembuatan }\end{array}$ & $\begin{array}{c}\text { Nama } \\
\text { kinematograf }\end{array}$ & Judul sekuen & Keterangan gambar \\
\hline $3 m-p$ & & & & $\begin{array}{l}\text { Ritual korban di lembah Ndona, } \\
\text { Flores. Penyembelihan ayam, } \\
\text { pemercikan darahnya, berdoa } \\
\text { pada dewa }\end{array}$ \\
\hline \multicolumn{5}{|c|}{ Mitos Nias (dalam bahasa Indonesia) } \\
\hline $4 a / b / c$ & $1926-1928$ & Iep Ochse & $\begin{array}{l}\text { Orang Eropa sedang } \\
\text { berjalan-jalan }\end{array}$ & $\begin{array}{l}\text { Orang Eropa, naik kuda, disertai } \\
\text { kuli, Nias } \\
\text { Berkuda lewat sungai dan } \\
\text { kampung }\end{array}$ \\
\hline $5 a$ & 1922 & Tak dikenal & Gambaran desa Nias & $\begin{array}{l}\text { Pemandangan kampung di desa } \\
\text { Hilisi Maetona, Nias. Orang-orang } \\
\text { membawa batang bambu berisi air }\end{array}$ \\
\hline $5 b$ & 1927 & Iep Ochse & & $\begin{array}{l}\text { Penduduk desa menaiki tangga } \\
\text { menuju desa Pawematelua, Nias } \\
\text { Selatan }\end{array}$ \\
\hline $5 c$ & 1922 & Tak dikenal & & $\begin{array}{l}\text { Pemandangan desa, ibu } \\
\text { memandikan anak, Hilisi Maetona, } \\
\text { Nias }\end{array}$ \\
\hline $5 \mathrm{~d} / \mathrm{e} / \mathrm{f}$ & 1927 & Iep Ochse & & $\begin{array}{l}\text { Seorang dukun menabuh } \\
\text { genderang dan berdoa untuk } \\
\text { menyembuhkan pasien, } \\
\text { Pawematelua, Nias Selatan }\end{array}$ \\
\hline $5 g$ & 1927 & Iep Ochse & & Anak kecil menaiki takhta batu \\
\hline $5 \mathrm{~h}$ & 1927 & Iep Ochse & & Dukun sedang memeriksa pasien \\
\hline $5 i$ & 1927 & Iep Ochse & & $\begin{array}{l}\text { Tetua adat berpose di depan } \\
\text { rumah adat }\end{array}$ \\
\hline $5 \mathrm{j}-\mathrm{n}$ & & & & $\begin{array}{l}\text { Pejabat pamongpraja Eropa } \\
\text { berpidato di depan penduduk desa } \\
\text { Nias }\end{array}$ \\
\hline \multicolumn{5}{|l|}{ Lagu Nias } \\
\hline $6 a$ & 1927 & Willy Mullens & Penebangan hutan & $\begin{array}{l}\text { Penebangan hutan untuk } \\
\text { penyiapan lahan perkebunan } \\
\text { karet, Sumatra }\end{array}$ \\
\hline $6 b$ & 1927 & Willy Mullens & & $\begin{array}{l}\text { Orang Eropa memberi petunjuk } \\
\text { kuli }\end{array}$ \\
\hline $6 c$ & 1920 & Miller & & Kuli menebang pohon \\
\hline $6 \mathrm{~d} / \mathrm{e}$ & 1927 & Willy Mullens & & Pembakaran kayu tebangan \\
\hline $7 a$ & 1926-1928 & Iep Ochse & Kapal baling air & $\begin{array}{l}\text { Kapal berbaling-baling di sungai } \\
\text { Barito }\end{array}$ \\
\hline $7 b$ & 1930 & $\begin{array}{l}\text { Hendrik } \\
\text { Tillema }\end{array}$ & & $\begin{array}{l}\text { Pemandangan tepi sungai Barito } \\
\text { dilihat dari kapal baling-baling air }\end{array}$ \\
\hline $7 \mathrm{c}$ & 1928 & Iep Ochse & & $\begin{array}{l}\text { Kuli memasukkan batubara di } \\
\text { ketel kapal }\end{array}$ \\
\hline $7 d-i$ & 1928 & Iep Ochse & & $\begin{array}{l}\text { Berbagai pemandangan di kapal, } \\
\text { kegiatan para penumpang, kapten } \\
\text { di ruang kemudi dan pekerja di } \\
\text { ruang mesin }\end{array}$ \\
\hline $7 \mathrm{j}$ & 1928 & Iep Ochse & & $\begin{array}{l}\text { Gelombang di belakang kapal, } \\
\text { perahu-perahu kecil mengikuti } \\
\text { kapal dari kanan dan kiri }\end{array}$ \\
\hline $8 \mathrm{a}$ & 1924 & Willy Mullens & Tambang minyak & $\begin{array}{l}\text { Pengeboran minyak di seputar } \\
\text { sungai Musi, Palembang }\end{array}$ \\
\hline
\end{tabular}




\begin{tabular}{|c|c|c|c|c|}
\hline $\begin{array}{c}\text { Nomor } \\
\text { urut shot }\end{array}$ & $\begin{array}{c}\text { Tahun } \\
\text { pembuatan }\end{array}$ & $\begin{array}{c}\text { Nama } \\
\text { kinematograf }\end{array}$ & Judul sekuen & Keterangan gambar \\
\hline $8 b-h$ & & Willy Mullens & & $\begin{array}{l}\text { Berbagai kegiatan pengeboran } \\
\text { minyak. Gerak mekanis pompa } \\
\text { angguk }\end{array}$ \\
\hline \multicolumn{5}{|c|}{ Serat Kalatidha } \\
\hline $9 a / b$ & 1926-1928 & Iep Ochse & Lokomotif/kereta api & $\begin{array}{l}\text { Lokomotif/kereta api. } \\
\text { Pemandangan di Jawa Barat, } \\
\text { kapal melewati jembatan besi; } \\
\text { kemungkinan dibangun oleh Eiffel }\end{array}$ \\
\hline $9 d / e / f$ & $1926-1928$ & Iep Ochse & & $\begin{array}{l}\text { Pemandangan sawah dan desa di } \\
\text { Jawa dari kereta api }\end{array}$ \\
\hline $10 a / b$ & 1920 & H. J. Flindt & $\begin{array}{l}\text { Kedatangan kereta } \\
\text { api }\end{array}$ & $\begin{array}{l}\text { Kedatangan kereta api di stasiun } \\
\text { Tanjung Priok }\end{array}$ \\
\hline 11 & 1920 & H. J. Flindt & Gedung stasiun & $\begin{array}{l}\text { Stasiun Tanjung Priok, penumpang } \\
\text { baru turun dari kereta }\end{array}$ \\
\hline $12 a-d$ & 1927 & Willy Mullens & Bus hotel & $\begin{array}{l}\text { Bus hotel Homann, berkeliling } \\
\text { kota Bandung, penumpang turun } \\
\text { di depan hotel }\end{array}$ \\
\hline 13 & 1912 & $\begin{array}{l}\text { Johann } \\
\text { Lamster }\end{array}$ & Restoran & $\begin{array}{l}\text { Restoran Grand Hotel Java, } \\
\text { Weltevreden, Batavia }\end{array}$ \\
\hline \multicolumn{5}{|l|}{ Lagu latar } \\
\hline 14 & 1912 & $\begin{array}{l}\text { Johann } \\
\text { Lamster }\end{array}$ & $\begin{array}{l}\text { Orang Eropa } \\
\text { berbelanja }\end{array}$ & $\begin{array}{l}\text { Orang Eropa naik mobil dan } \\
\text { berbelanja, Yogyakarta }\end{array}$ \\
\hline 15 & 1912 & $\begin{array}{l}\text { Johann } \\
\text { Lamster }\end{array}$ & Gerbang Keraton & $\begin{array}{l}\text { Gerobak dan orang-orang berjalan } \\
\text { menuju pintu gerbang keraton } \\
\text { Yogya }\end{array}$ \\
\hline $16 \mathrm{a}$ & $1926-1928$ & Iep Ochse & $\begin{array}{l}\text { Gambaran pasar dan } \\
\text { jalan }\end{array}$ & $\begin{array}{l}\text { Pemandangan pasar dan jalan di } \\
\text { Batavia }\end{array}$ \\
\hline $16 b$ & $1926-1928$ & Iep Ochse & & Tiga anak kecil merokok, Bali \\
\hline $16 \mathrm{~d} / \mathrm{e}$ & $1926-1928$ & Iep Ochse & & Pemandangan pasar di Batavia \\
\hline $16 f$ & 1927 & Willy Mullens & & Pemandangan pasar di Surabaya \\
\hline $16 \mathrm{~g}$ & $1926-1928$ & Iep Ochse & & $\begin{array}{l}\text { Anak kecil menyusu pada ibunya } \\
\text { sambil merokok, Bali }\end{array}$ \\
\hline $16 \mathrm{~h} / \mathrm{i} / \mathrm{j}$ & & & & $\begin{array}{l}\text { Ibu dan anak di bawah pohon } \\
\text { beringin; ibu sedang berjualan; } \\
\text { pemandangan pasar, Batavia }\end{array}$ \\
\hline $17 \mathrm{a}$ & 1927 & Iep Ochse & Sekolah Dasar & $\begin{array}{l}\text { Sekolah Kristen-Cina (Christelijk } \\
\text { Hollandsch Chinese School), } \\
\text { Mojowarno, Jatim }\end{array}$ \\
\hline $17 b / c / d$ & 1927 & Iep Ochse & & $\begin{array}{l}\text { Ruang kelas, guru sedang memberi } \\
\text { contoh cara mengucapkan bunyi } \\
\text { bahasa }\end{array}$ \\
\hline $17 e-j$ & 1927 & Iep Ochse & & $\begin{array}{l}\text { Sekolah desa di Jawa Timur. } \\
\text { Seorang murid perempuan } \\
\text { "mengecat" putih mukanya; anak- } \\
\text { anak menulis menggunakan batu } \\
\text { tulis dan anak batu tulis }\end{array}$ \\
\hline $17 \mathrm{k}$ & 1927 & Iep Ochse & & $\begin{array}{l}\text { Seorang murid menyontek pada } \\
\text { "anak kecil bertopi" (lihat shot } 1 \\
\text { dan 55e), Swaru, Jawa Timur }\end{array}$ \\
\hline 18 & 1928 & Iep Ochse & $\begin{array}{l}\text { Pawai anak-anak } \\
\text { sekolah }\end{array}$ & $\begin{array}{l}\text { Pawai anak-anak dalam rangka } \\
\text { Koninginnedag, Manokwari }\end{array}$ \\
\hline
\end{tabular}




\begin{tabular}{|c|c|c|c|c|}
\hline $\begin{array}{l}\text { Nomor } \\
\text { urut shot }\end{array}$ & $\begin{array}{c}\text { Tahun } \\
\text { pembuatan }\end{array}$ & $\begin{array}{c}\text { Nama } \\
\text { kinematograf }\end{array}$ & Judul sekuen & Keterangan gambar \\
\hline 19a-f & 1917 & L. Ph. de Bussy & Kedatangan kuli & $\begin{array}{l}\text { Kedatangan kuli Cina di Belawan, } \\
\text { pemeriksaan kesehatan dan } \\
\text { pencatatan administrasi kuli. } \\
\text { Kuli dari Cina itu akan bekerja di } \\
\text { perkebunan Deli }\end{array}$ \\
\hline $19 \mathrm{~g}-\mathrm{O}$ & $1926-1928$ & Iep Ochse & & $\begin{array}{l}\text { Kedatangan kuli dari Cina } \\
\text { di Tanjung Pandan, Biliton. } \\
\text { Pemeriksaan kesehatan, pencatatan } \\
\text { dactyloscopie, pembuatan kontrak }\end{array}$ \\
\hline $19 p$ & 1917 & L. Ph. de Bussy & & $\begin{array}{l}\text { Kuli yang baru datang sedang } \\
\text { mandi, Deli }\end{array}$ \\
\hline $19 q-y$ & 1926 & Iep Ochse & & $\begin{array}{l}\text { Pemeriksaaan kesehatan, } \\
\text { penggundulan kepala para kuli di } \\
\text { karantina Biliton }\end{array}$ \\
\hline \multicolumn{5}{|c|}{ Sajak Rendra (dalam bahasa Indonesia) } \\
\hline $20 a-h$ & $1926-1928$ & Iep Ochse & Tambang Biliton & $\begin{array}{l}\text { Berbagai kegiatan para kuli di } \\
\text { pertambangan timah Biliton. }\end{array}$ \\
\hline $21 a / b$ & 1927 & Iep Ochse & Penebangan hutan & $\begin{array}{l}\text { Penebangan hutan dan penyiapan } \\
\text { lahan perkebunan di Deli }\end{array}$ \\
\hline $21 \mathrm{c}$ & 1922 & H. Melman & & $\begin{array}{l}\text { Orang Eropa memberi petunjuk } \\
\text { pada kuli yang sedang } \\
\text { mencangkul, Pemantang Siantar }\end{array}$ \\
\hline $21 d$ & 1927 & Iep Ochse & & $\begin{array}{l}\text { Kuli sedang mencangkul, } \\
\text { perkebunan tembakau Klaten }\end{array}$ \\
\hline \multicolumn{5}{|l|}{ Lagu latar } \\
\hline $22 \mathrm{a}$ & 1917 & L. Ph. de Bussy & $\begin{array}{l}\text { Pembangunan } \\
\text { gudang tembakau }\end{array}$ & $\begin{array}{l}\text { Kuli membangun bedeng } \\
\text { pengeringan tembakau }\end{array}$ \\
\hline $22 \mathrm{~b} / \mathrm{c} / \mathrm{d}$ & 1927 & Willy Mullens & & $\begin{array}{l}\text { Kuli membangun bedeng } \\
\text { pengeringan tembakau di Deli }\end{array}$ \\
\hline $23 a / b / c$ & 1927 & Willy Mullens & $\begin{array}{l}\text { Tempat mandi bambu } \\
\text { dan sumur }\end{array}$ & $\begin{array}{l}\text { Anak perempuan sedang mandi, } \\
\text { mempergunakan batang bambu } \\
\text { sebagai saluran air }\end{array}$ \\
\hline $23 d$ & 1917 & L. Ph. de Bussy & & $\begin{array}{l}\text { Anak laki-laki sedang mandi di } \\
\text { pancuran }\end{array}$ \\
\hline $24 a$ & 1927 & Iep Ochse & Penggarap tanah & $\begin{array}{l}\text { Kuli mencangkul di perkebunan } \\
\text { tembakau Klaten }\end{array}$ \\
\hline $24 b-f$ & 1927 & Iep Ochse & & $\begin{array}{l}\text { Anak-anak mencari dan } \\
\text { mengumpulkan ulat di } \\
\text { perkebunan tembakau }\end{array}$ \\
\hline $25 a / b$ & 1928 & Iep Ochse & $\begin{array}{l}\text { Membakar batu } \\
\text { makam }\end{array}$ & $\begin{array}{l}\text { Sejumlah orang memecah batu } \\
\text { gunung untuk nisan, Sumba }\end{array}$ \\
\hline $25 c$ & 1928 & Iep Ochse & & $\begin{array}{l}\text { Seorang laki-laki tua yang } \\
\text { dibuatkan nisan }\end{array}$ \\
\hline $25 \mathrm{~d}-\mathrm{g}$ & 1928 & Iep Ochse & & $\begin{array}{l}\text { Ratusan orang Sumba sedang } \\
\text { mendorong bongkahan batu nisan } \\
\text { ke desa }\end{array}$ \\
\hline $26 a-e$ & 1924 & Willi Rach & $\begin{array}{l}\text { Pengorbanan } \\
\text { kambing }\end{array}$ & $\begin{array}{l}\text { Ritual korban kambing; } \\
\text { pemotongan dan pemercikan } \\
\text { darah. Larantuka, Flores }\end{array}$ \\
\hline $27 a-d$ & 1926-1928 & Iep Ochse & Panen tembakau & $\begin{array}{l}\text { Kegiatan seputar panen tembakau } \\
\text { di Klaten }\end{array}$ \\
\hline $27 \mathrm{e}$ & 1927 & Willy Mullens & & $\begin{array}{l}\text { Kegiatan pemilahan daun } \\
\text { tembakau di Deli }\end{array}$ \\
\hline
\end{tabular}




\begin{tabular}{|c|c|c|c|c|}
\hline $\begin{array}{l}\text { Nomor } \\
\text { urut shot }\end{array}$ & $\begin{array}{c}\text { Tahun } \\
\text { pembuatan }\end{array}$ & $\begin{array}{c}\text { Nama } \\
\text { kinematograf }\end{array}$ & Judul sekuen & Keterangan gambar \\
\hline $27 f / g / h$ & 1917 & L. Ph. de Bussy & & $\begin{array}{l}\text { Seorang mandor Eropa memeriksa } \\
\text { pemilahan daun tembakau oleh } \\
\text { para kuli; daerah Kedu, Jateng }\end{array}$ \\
\hline $27 i-p$ & $1926-1928$ & Iep Ochse & & $\begin{array}{l}\text { Kegiatan pengepakan daun } \\
\text { tembakau di Klaten. Pengiriman } \\
\text { tembakau yang sudah dipak di } \\
\text { pelabuhan Semarang } \\
\end{array}$ \\
\hline $28 \mathrm{a}-\mathrm{g}$ & 1928 & Iep Ochse & Banjarmasin & $\begin{array}{l}\text { Berbagai pemandangan di } \\
\text { Banjarmasin dilihat dari kapal } \\
\text { yang sedang melintas sungai } \\
\text { Barito }\end{array}$ \\
\hline \multicolumn{5}{|c|}{ Sajak Sitor Situmorang (dalam bahasa Indonesia) } \\
\hline 29a-e & $1926-1928$ & Iep Ochse & Gambaran kota & $\begin{array}{l}\text { Berbagai pemandangan kota } \\
\text { Surabaya dilihat dari trem }\end{array}$ \\
\hline $30 a-1$ & 1924 & Willy Mullens & Pabrik kaleng & $\begin{array}{l}\text { Berbagai kegiatan di pabrik kaleng } \\
\text { milik perusahaan minyak BPM di } \\
\text { Surabaya }\end{array}$ \\
\hline $30 \mathrm{~m}$ & 1924 & Willy Mullens & & $\begin{array}{l}\text { Seorang Eropa sedang memberi } \\
\text { petunjuk pengangkutan kaleng ke } \\
\text { kapal pada kuli di Sumba }\end{array}$ \\
\hline $31 \mathrm{a} / \mathrm{b}$ & 1927 & Iep Ochse & $\begin{array}{l}\text { Orang-orang Eropa } \\
\text { yang berjalan-jalan }\end{array}$ & $\begin{array}{l}\text { Orang Eropa berjalan disertai kuli } \\
\text { panggul di belakangnya }\end{array}$ \\
\hline $31 \mathrm{c}$ & 1924 & Willy Rach & & $\begin{array}{l}\text { Misionaris Eropa jatuh dari } \\
\text { kudanya di sungai }\end{array}$ \\
\hline $32 \mathrm{a} / \mathrm{b}$ & 1927 & Iep Ochse & Misi & $\begin{array}{l}\text { Kegiatan linguis Onvlee, anggota } \\
\text { perkumpulan Alkitab Belanda, di } \\
\text { Sumba }\end{array}$ \\
\hline $32 c / d / e$ & 1930 & Simon P. Buis & & $\begin{array}{l}\text { Seorang pastor mengajar anak- } \\
\text { anak membuat tanda salib, di } \\
\text { Flores }\end{array}$ \\
\hline $32 \mathrm{f}-\mathrm{i}$ & 1927 & Iep Ochse & & $\begin{array}{l}\text { Jemaat mendengarkan khotbah } \\
\text { pendeta Van Dijk di Sumba }\end{array}$ \\
\hline $32 \mathrm{j}-\mathrm{m}$ & 1924 & Willy Rach & & $\begin{array}{l}\text { Kegiatan pembaptisan penduduk } \\
\text { pribumi oleh seorang pastor di } \\
\text { Flores }\end{array}$ \\
\hline $32 \mathrm{n} / \mathrm{o}$ & 1924 & Willy Rach & & $\begin{array}{l}\text { Para pastor sedang mengecat } \\
\text { patung-patung suci }\end{array}$ \\
\hline $32 \mathrm{p} / \mathrm{q} / \mathrm{r}$ & 1924 & Willy Rach & & $\begin{array}{l}\text { Seorang pastor sedang mengajar } \\
\text { anak sekolah memainkan alat } \\
\text { musik }\end{array}$ \\
\hline $33 a / b$ & 1926 & Iep Ochse & $\begin{array}{l}\text { Pemeliharaan } \\
\text { kesehatan }\end{array}$ & $\begin{array}{l}\text { Kegiatan operasi di selasar suatu } \\
\text { rumah sakit }\end{array}$ \\
\hline $33 c-i$ & 1927 & Tak dikenal & & $\begin{array}{l}\text { Berbagai gambar pasien cacar, } \\
\text { lepra, dan frambusia bersama para } \\
\text { perawat }\end{array}$ \\
\hline $34 a-g$ & 1927 & Willy Mullens & $\begin{array}{l}\text { Pemandian dan } \\
\text { pengkafanan jenazah }\end{array}$ & $\begin{array}{l}\text { Kegiatan memandikan, } \\
\text { mengkafani, dan memakamkan } \\
\text { jenazah di Flores }\end{array}$ \\
\hline \multicolumn{5}{|c|}{ Tembang Bharatayudha (dalam bahasa Jawa) } \\
\hline $35 a / b / c$ & 1927 & Willy Mullens & Pemakaman & $\begin{array}{l}\text { Upacara penguburan di } \\
\text { pegunungan Tengger }\end{array}$ \\
\hline $36 a-f$ & 1930 & Tidak dikenal & Kapuk & $\begin{array}{l}\text { Kegiatan pengolahan sampai } \\
\text { dengan pengepakan dan } \\
\text { pengiriman kapuk di Jawa Tengah }\end{array}$ \\
\hline
\end{tabular}




\begin{tabular}{|c|c|c|c|c|}
\hline $\begin{array}{l}\text { Nomor } \\
\text { urut shot }\end{array}$ & $\begin{array}{c}\text { Tahun } \\
\text { pembuatan }\end{array}$ & $\begin{array}{c}\text { Nama } \\
\text { kinematograf }\end{array}$ & Judul sekuen & Keterangan gambar \\
\hline \multicolumn{5}{|c|}{ Puisi Vincent Monnikendam (dalam bahasa Indonesia) } \\
\hline $37 \mathrm{a} / \mathrm{b}$ & 1926 & Iep Ochse & Orang-orang Eropa & $\begin{array}{l}\text { Gambar keluarga Eropa dan } \\
\text { pembantunya }\end{array}$ \\
\hline $37 \mathrm{c}-\mathrm{g}$ & 1931 & Tidak dikenal & & Rekaman pesta orang Eropa \\
\hline $37 \mathrm{~h}$ & 1927 & Iep Ochse & & Pacuan kuda \\
\hline $37 i$ & 1920 & Tidak dikenal & & Seorang joki sedang memacu kuda \\
\hline $38 \mathrm{a} / \mathrm{b}$ & $1926-1928$ & Iep Ochse & Nieuw Guinea & Sekelompok orang Papua menari \\
\hline $38 \mathrm{c}-\mathrm{j}$ & 1926 & Richard Peck & & $\begin{array}{l}\text { Anggota ekspedisi sedang } \\
\text { berinteraksi dengan orang-orang } \\
\text { Papua }\end{array}$ \\
\hline $38 \mathrm{k}$ & 1926 & Richard Peck & & $\begin{array}{l}\text { Pengukuran cranology penduduk } \\
\text { Irian oleh anggota ekspedisi Eropa }\end{array}$ \\
\hline 381 & 1926 & Richard Peck & & $\begin{array}{l}\text { Kapal terbang amfibi ekspedisi } \\
\text { Stirling sedang mendarat }\end{array}$ \\
\hline $39 \mathrm{a}$ & $1926-1928$ & Iep Ochse & Pabrik gula & $\begin{array}{l}\text { Lokomotif di pabrik gula di Jawa } \\
\text { Timur }\end{array}$ \\
\hline $39 b-s$ & $1926-1928$ & Willy Mullens & & $\begin{array}{l}\text { Kegiatan di suatu pabrik } \\
\text { gula mulai dari panen tebu, } \\
\text { penggilingan tebu sampai } \\
\text { pengepakan dalam karung sampai } \\
\text { pengiriman }\end{array}$ \\
\hline $40 a-i$ & $1926-1928$ & Iep Ochse & Tarian Nias & $\begin{array}{l}\text { Tarian oleh sekelompok laki-laki } \\
\text { Nias. Wajah laki-laki pada shot } 5 n \\
\text { terlihat lagi di sini. }\end{array}$ \\
\hline $41 \mathrm{a} / \mathrm{b}$ & 1924 & Willy Mullens & Kota & $\begin{array}{l}\text { Mobil pengangkut milik pabrik } \\
\text { minuman keras Oud, Surabaya }\end{array}$ \\
\hline $41 c-f$ & 1924 & Willy Mullens & & $\begin{array}{l}\text { Lalu lintas di kota Surabaya; truk } \\
\text { BPM dan pabrik minuman Oud } \\
\text { sedang melintas }\end{array}$ \\
\hline $41 \mathrm{~g}$ & 1927 & Willy Mullens & & $\begin{array}{l}\text { Pemandangan di pompa bensin di } \\
\text { depan toko Piet, Surabaya }\end{array}$ \\
\hline \multicolumn{5}{|c|}{ Tembang dari Cianjur (dalam bahasa Sunda) } \\
\hline $42 a-g$ & 1927 & Willy Mullens & $\begin{array}{l}\text { Orang Eropa di toko } \\
\text { Piet }\end{array}$ & $\begin{array}{l}\text { Keramaian di toko Piet. Para } \\
\text { pembeli Eropa sedang berbelanja }\end{array}$ \\
\hline 43 & $1926-1928$ & Iep Ochse & Kejadian di kota & $\begin{array}{l}\text { Seorang anak terlihat menunggui } \\
\text { barang-barang pindahan }\end{array}$ \\
\hline $44 a$ & 1917 & L. Ph. de Bussy & Kedatangan kuli & $\begin{array}{l}\text { Kuli-kuli dari Jawa keluar dari } \\
\text { gerbong kereta }\end{array}$ \\
\hline $44 \mathrm{~b}$ & $1917 \& 1926$ & Iep Ochse & & $\begin{array}{l}\text { Pemeriksaan barang bawaan kuli } \\
\text { oleh orang Eropa di depan pintu } \\
\text { masuk karantina }\end{array}$ \\
\hline $44 c-j$ & 1917 & L. Ph. de Bussy & & $\begin{array}{l}\text { Kuli yang baru datang berkumpul } \\
\text { di aula mendapat pemeriksaan } \\
\text { kesehatan, pil malaria, dan } \\
\text { makanan }\end{array}$ \\
\hline \multicolumn{5}{|c|}{ Serat Kalatidha (dalam bahasa Jawa) } \\
\hline $45 \mathrm{a}$ & 1926-1928 & Iep Ochse & Gambaran kota & Jembatan gantung di Banjarmasin \\
\hline $45 b$ & $1926-1928$ & Iep Ochse & & $\begin{array}{l}\text { Sebuah trem melintas di depan } \\
\text { istana gubernur di Batavia }\end{array}$ \\
\hline $45 c$ & 1924 & Willy Mullens & & $\begin{array}{l}\text { Dua orang Eropa sedang minum } \\
\text { minman keras dan mengisap } \\
\text { cerutu }\end{array}$ \\
\hline
\end{tabular}




\begin{tabular}{|c|c|c|c|c|}
\hline $\begin{array}{l}\text { Nomor } \\
\text { urut shot }\end{array}$ & $\begin{array}{c}\text { Tahun } \\
\text { pembuatan }\end{array}$ & $\begin{array}{c}\text { Nama } \\
\text { kinematograf }\end{array}$ & Judul sekuen & Keterangan gambar \\
\hline $45 \mathrm{~d} / \mathrm{e}$ & 1920 & Miller & & $\begin{array}{l}\text { Para pekebun tembakau sedang } \\
\text { bersantai di club perkebunan } \\
\text { tembakau di Deli }\end{array}$ \\
\hline $46 a-m$ & 1922 & Tak dikenal & Pembantaian buaya & $\begin{array}{l}\text { Perburuan dan pembantaian } \\
\text { massal buaya di sungai Musi }\end{array}$ \\
\hline $47 a-g$ & 1926 & Willy Mullens & Kampung/desa & $\begin{array}{l}\text { Pemandangan kampung dan } \\
\text { desa di Jawa serta kegiatan para } \\
\text { penduduknya }\end{array}$ \\
\hline $47 \mathrm{~h}$ & 1928 & Iep Ochse & & $\begin{array}{l}\text { Seorang perempuan Bali sedang } \\
\text { memintal }\end{array}$ \\
\hline \multicolumn{5}{|c|}{ Serat Wulang Reh (dalam bahasa Jawa) } \\
\hline $48 \mathrm{a}-\mathrm{f}$ & $1926-1928$ & Iep Ochse & Tempat mandi & $\begin{array}{l}\text { Sejumlah perempuan dan anak- } \\
\text { anak sedang mandi di tempat } \\
\text { mandi di Bali }\end{array}$ \\
\hline $48 \mathrm{~g}$ & $1926-1928$ & Iep Ochse & & Tempat memandikan kuda \\
\hline $49 a-p$ & 1925 & \begin{tabular}{|l|} 
Louis van \\
Vuuren \\
\end{tabular} & $\begin{array}{l}\text { Penyembelihan } \\
\text { kerbau }\end{array}$ & $\begin{array}{l}\text { Upacara penguburan di Toraja. } \\
\text { Ritual penyembelihan kerbau. }\end{array}$ \\
\hline $50 \mathrm{a}$ & 1927 & Willy Mullens & Kompleks industri & $\begin{array}{l}\text { Pelabuhan dan kegiatan para kuli } \\
\text { di Balikpapan }\end{array}$ \\
\hline $50 \mathrm{~b}$ & 1925 & Ph. G. Carli & & Lokomotif di bengkel \\
\hline $50 \mathrm{c}$ & 1924 & Willy Mullens & & $\begin{array}{l}\text { Generator pembangkit listrik yang } \\
\text { sedang berputar }\end{array}$ \\
\hline $50 \mathrm{~d} / \mathrm{e}$ & 1925 & Ph. G. Carli & & Ujicoba lokomotif di bengkel \\
\hline $50 \mathrm{f} / \mathrm{g} / \mathrm{h}$ & 1924 & Willy Mullens & & $\begin{array}{l}\text { Generator pembangkit } \\
\text { listrik. Beberapa kuli sedang } \\
\text { memperbaiki. }\end{array}$ \\
\hline $50 \mathrm{i}$ & 1925 & Ph. G. Carli & & $\begin{array}{l}\text { Kegiatan di tempat kerja bengkel } \\
\text { lokomotif }\end{array}$ \\
\hline $50 \mathrm{j} / \mathrm{k}$ & 1924 & Willy Mullens & & $\begin{array}{l}\text { Kuli sedang membuat drum } \\
\text { minyak }\end{array}$ \\
\hline 501 & 1925 & Ph. G. Carli & & $\begin{array}{l}\text { Pemandangan di bengkel } \\
\text { lokomotif }\end{array}$ \\
\hline $50 \mathrm{~m}$ & 1925 & Tassilo Adam & & $\begin{array}{l}\text { Kuli mendorong lori berisi residu } \\
\text { minyak }\end{array}$ \\
\hline $50 n-q$ & 1925 & Ph. G. Carli & & $\begin{array}{l}\text { Para kuli sedang mendorong } \\
\text { lokomotif yang baru jadi menuju } \\
\text { rel untuk uji coba }\end{array}$ \\
\hline $50 \mathrm{r} / \mathrm{s} / \mathrm{t}$ & 1926 & Iep Ochse & & $\begin{array}{l}\text { Sejumlah kuli Jawa dan Cina } \\
\text { sedang makan sambil bersenda- } \\
\text { gurau di warung }\end{array}$ \\
\hline $51 \mathrm{a}-\mathrm{g}$ & 1928 & Iep Ochse & $\begin{array}{l}\text { Selamatan dan } \\
\text { penghargaan pada } \\
\text { kuli }\end{array}$ & $\begin{array}{l}\text { Pesta penganugerahan bintang } \\
\text { pada kuli kontrak Jawa yang } \\
\text { telah setia mengabdi. Penyematan } \\
\text { bintang dan pengalungan bunga } \\
\text { dilakukan oleh perempuan Eropa, } \\
\text { istri pejabat pabrik gula }\end{array}$ \\
\hline \multicolumn{5}{|c|}{ Lagu Sunda } \\
\hline $52 \mathrm{a}-\mathrm{e}$ & 1920 & H. Melman & Perahu & $\begin{array}{l}\text { Orang Eropa dan pribumi berjalan- } \\
\text { jalan dengan perahu }\end{array}$ \\
\hline \multicolumn{5}{|c|}{ Puisi Vincent Monnikendam (dalam bahasa Indonesia) } \\
\hline $53 a-h$ & 1924 & Willy Rach & Pemakaman & Upacara penguburan di Flores \\
\hline
\end{tabular}




\begin{tabular}{|l|l|l|l|l|}
\hline $\begin{array}{c}\text { Nomor } \\
\text { urut shot }\end{array}$ & $\begin{array}{c}\text { Tahun } \\
\text { pembuatan }\end{array}$ & $\begin{array}{c}\text { Nama } \\
\text { kinematograf }\end{array}$ & Judul sekuen & \multicolumn{1}{|c|}{ Keterangan gambar } \\
\hline $54 a-d$ & 1924 & Willy Rach & Pengorbanan kerbau & $\begin{array}{l}\text { Ritual pemotongan kerbau dan } \\
\text { tarian ritual penguburan di } \\
\text { kepulauan Sunda Kecil }\end{array}$ \\
\hline $55 a$ & 1926 & Iep Ochse & Epilog & Epilog: film hitam \\
\hline $55 b$ & 1924 & Willy Mullens & & $\begin{array}{l}\text { Anak perempuan dari kepulauan } \\
\text { Sunda Kecil }\end{array}$ \\
\hline $55 c$ & $1926-1928$ & Iep Ochse & & Seorang kuli Cina di Balikpapan \\
\hline 55d & $1926-1928$ & Iep Ochse & Papua, Irian Jaya \\
\hline 55e & & & $\begin{array}{l}\text { Anak kecil bertopi (lihat shot 1 dan } \\
\text { 17k) }\end{array}$ \\
\hline Puisi Subagio Sastrowardojo (dalam bahasa Indonesia) & \\
\hline
\end{tabular}

